Federal Reserve Bank of Dallas

Globalization and Monetary Policy Institute

Working Paper No. 27

http://www.dallasfed.org/assets/documents/institute/wpapers/2009/0027.pdf

\title{
International Portfolios, Capital Accumulation and Foreign Assets Dynamics*
}

\author{
Nicolas Coeurdacier \\ London Business School and CEPR \\ Robert Kollmann \\ ECARES, Université Libre de Bruxelles, Université Paris XII and CEPR \\ Philippe Martin \\ Université Paris I Panthéon-Sorbonne, Paris School of Economics and CEPR
}

January 2009

\begin{abstract}
Despite the liberalization of capital flows among OECD countries, equity home bias remains sizable. We depart from the two familiar explanations of equity home bias: transaction costs that impede international diversification, and terms of trade responses to supply shocks that provide risk sharing, so that there is little incentive to hold diversified portfolios. We show that the interaction of the following ingredients generates a realistic equity home bias: capital accumulation, shocks to the efficiency of physical investment, as well as international trade in stocks and bonds. In our model, domestic stocks are used to hedge fluctuations in local wage income. Terms of trade risk is hedged using bonds denominated in local goods and in foreign goods. In contrast to related models, the low level of international diversification does not depend on strongly countercyclical terms of trade. The model also reproduces the cyclical dynamics of foreign asset positions and of international capital flows.
\end{abstract}

JEL codes: F2, F3, G1

\footnotetext{
* Nicolas Coeurdacier, Department of Economics, London Business School, Regent's Park, London NW1 4SA, United Kingdom; + 44-20-7-000-8433. ncoeurdacier@london.edu. Robert Kollmann, ECARES, Université Libre de Bruxelles, 50 Av. Franklin Roosevelt, CP 114, B-1050 Brussels, Belgium. 32-2-65030-75. robert_kollmann@yahoo.com. Phillipe Martin, Université Paris I, 106-112 Blvd de l.Hôpital, 75013 Paris, France.+33-0-144078265. philippe.martin@univ-paris1.fr. We thank Kosuke Aoki, Matthias Doepke, Stéphane Guibaud, Viktoria Hnatkovska, Mathias Hoffmann and Giovanni Lombardo for detailed and constructive discussions. For comments and advice, we are also grateful to Lieven Baele, Luca Dedola, Pierre-Olivier Gourinchas, Harald Hau, Jonathan Heathcote, Akito Matsumoto, Werner Roeger and Alan Sutherland, and to workshop participants at RES 2008, SED 2008, IMF-JIE conference "International Macro-Finance,” Bundesbank Spring conference, ESSIM (CEPR), EU Commission (DG ECFIN), at EUI (Florence) and at the Universities of Zurich and Ghent. Robert Kollmann thanks ECARES, the National Bank of Belgium and the EU Commission (DG ECFIN) for financial support. Views expressed in this paper are those of the authors and do not necessarily reflect the views of the Federal Reserve Bank of Dallas or the Federal Reserve System.
} 


\section{Introduction}

Cross-country capital flows have increased greatly, since the liberalization of international capital markets two decades ago (e.g., Lane and Milesi-Feretti (2003, 2005, 2006)). Equity home bias, while less severe than in earlier decades, remains sizable and is observed in all industrialized countries (see French and Poterba (1991) for early evidence and Sercu and Vanpée (2007) for a recent survey). There are broadly two classes of explanations for the persisting equity home bias. The first one centers on transaction costs and informational barriers in cross-border financial transactions and suggests that international risk sharing is insufficient. ${ }^{1}$ The second one focuses on the possibility that terms of trade changes in response to supply shocks may provide international insurance against these shocks, so that even a portfolio with home bias delivers efficient international risk sharing (Cole and Obstfeld (1991), Helpman and Razin (1978)).

Both types of explanations are helpful but are not without problems. Several authors have argued that frictions would have to be large to fully explain the equity home bias (French and Poterba (1991), Tesar and Werner (1995), Warnock (2002)). In order to interpret terms of trade changes as providing insurance (rather than a source of risk), the terms of trade would have to improve strongly after a negative supply shock. However, empirically the terms of trade are only weakly correlated with output (e.g., Backus, Kehoe and Kydland (1994)).

Using a two-country general equilibrium model with fully integrated financial markets, this paper shows that the interaction of the following ingredients is key for generating realistic equity home bias, without requiring strongly countercyclical terms of trade: capital accumulation, shocks to physical investment efficiency, and international trade in stocks and bonds denominated in local and foreign goods. ${ }^{2}$ In addition to standard TFP (total factor productivity) shocks, the model here assumes shock to investment efficiency (as in Greenwood, Hercowitz and Krusell (1997, 2000), Fisher (2002, 2006)), because recent empirical research suggests that those shocks are an important source of fluctuations in real activity (Justiniano and Primiceri (2006), Justiniano et al. (2007)).

By contrast, other recent general equilibrium models of international equity holdings (see Devereux

\footnotetext{
${ }^{1}$ See, e.g., Heathcote and Perri (2002, 2004), Martin and Rey (2004), Coeurdacier and Guibaud (2006), Tille and Van Wincoop (2007), and Van Nieuwerburgh and Veldkamp (2007) for recent studies on the role of frictions in international financial markets.

${ }^{2}$ Pavlova and Rigobon (2004, 2007), Engel and Matsumoto (2006) and Coeurdacier, Kollmann and Martin (2007) have previously analyzed equity portfolio choice in general equilibrium models with trade in bonds.
} 
and Sutherland (2006a,b) for references) have mostly assumed endowment economies, i.e. economies without production or capital accumulation - Heathcote and Perri (2007) is a notable exception discussed below. In such economies, households trade in international financial markets solely for consumption smoothing and risk sharing purposes so that the equity portfolio is structured to sustain net imports in states of nature where local production is low; this leads to local equity bias if relative Home equity returns rise (compared to Foreign returns) when the Home terms of trade improve and the Home real exchange rate appreciates, in response to a drop in the Home output. ${ }^{3}$ This condition however is not met in the data: empirically, the correlation between relative equity returns and the real exchange rate is low (Van Wincoop and Warnock (2007)).

We consider a model with capital accumulation because, as discussed by Obstfeld and Rogoff (1996), one of the key functions of international financial markets is to finance physical investment; empirically, productive investment is a key driver of fluctuations in net imports (Sachs (1981), Backus, Kehoe and Kydland (1994)). With two stocks and two bonds, and two types of (Home and Foreign) technology shocks (to TFP and physical investment efficiency), markets are effectively complete, up to a first order (linear) approximation of the model. The equilibrium portfolio is structured to optimally hedge fluctuations in the terms of trade and in labor incomes. ${ }^{4}$ Specifically, bonds are used for terms of trade hedging, since the difference between the pay-offs of bonds denominated in Home and Foreign goods is correlated with the terms of trade. Fluctuations in labor incomes are hedged through the equity portfolio. The key mechanism here is that fluctuations in investment generate a negative comovement between Home dividends and Home labor incomes (relative to their Foreign counterparts). A Home investment boom lowers Home dividend payments (to finance investment) and raises Home output and wage incomes(relative to foreign wages), under the realistic assumption (made here) that there is a local bias in investment spending. Thus, local equity offers a good hedge against movements in local labor incomes associated with investment fluctuations - which explains why equilibrium equity portfolios exhibit home bias, in the setting here. The predicted equity home bias only depends on the degree of home bias in investment spending, and on the labor share. In particular, it is independent of preference parameters. ${ }^{5}$

\footnotetext{
${ }^{3}$ See Uppal (1993), Coeurdacier (2005), Kollmann (2006b).

${ }^{4}$ See Adler and Dumas (1983) for early work that stresses exchange rate hedging as a determinant of portfolio choice. Baxter and Jermann (1997), Heathcote and Perri (2007), Engel and Matsumoto (2006), Bottazzi, Pesenti and Van Wincoop (1996), and Julliard (2002 and 2004), among others, discuss the hedging of labor income risk.

${ }^{5}$ Coeurdacier and Gourinchas (2008) provide a general discussion of the conditions under which equity portfolios are
} 
The closest paper to ours is Heathcote and Perri (2007) [HP henceforth] who were the first to investigate the importance of physical investment for equity portfolios. Trade in bonds, and the shocks to investment efficiency assumed here are the main difference between our model and HP. The HP model only generates realistic equity home bias if the terms of trade respond strongly to TFP shocks (or, equivalently, if preferences are "close enough" to log-separability between the two goods, as in a Cole and Obstfeld (1991) economy). Our model does not require strong terms of trade effects of productivity shocks - nevertheless, there is sizable equity home bias. This is important since the empirical evidence concerning the response of the terms of trade to technology shocks is mixed. ${ }^{6}$

Another paper close to ours is Engel and Matsumoto (2006) who analyze international equity portfolio choices in a model with money, sticky prices and trade in bonds, but without capital accumulation. Under price stickiness, the short run level of output is demand determined, so that a positive productivity shock leads to a fall in employment and labor income, but an increase in profits. Ownership of local equity is thus an effective hedge against labor income risk. In our model, local equity has a similar hedging property-but that property is driven by physical investment shocks (without requiring price stickiness).

A key contribution of the paper here is to explore the quantitative implications of the model regarding the dynamics of external asset positions and international capital flows. Gourinchas and Rey (2005), Tille (2005) and Lane and Milesi-Ferretti (2006) document empirically that fluctuations in the value of domestic and foreign assets induce external capital gains/losses that have a substantial effect on countries' net foreign asset positions (NFA). We show that the present model generates sizable international valuation effects. Here, fluctuations in a country's NFA are driven by asset price changes-NFA is thus predicted to have the time series properties of asset prices; in particular, the first difference of a country's NFA is predicted to be highly volatile and to have low serial correlation. We show that these predictions are consistent with the data. When there is a positive TFP or investment efficiency shock, net imports are predicted to rise on impact (due to a strong short run rise in investment), and to fall thereafter. As NFA equals the present value of current and future net imports, the NFA drops, on impact. Thus, the change in NFA is predicted to be countercyclical, which is likewise consistent with the data. Finally, the model independent of preference parameters.

${ }^{6}$ Corsetti, Dedola and Leduc (2006) argue that, empirically, a positive technology shocks triggers a terms of trade appreciation; Acemoglu and Ventura (2002) and Kollmann (2006c) provide evidence that higher productivity depreciates the terms-of-trade. 
generates sizable asset trades. ${ }^{7}$

We also show that our model has several appealing business cycle features. The investment efficiency shocks assumed here generate net exports and real exchange rate volatility that is larger-and thus closer to the data - than the volatility induced by TFP shocks. In the model here, a positive shock to a country's TFP raises that country's output while worsening its terms of trade; a country-specific shock to investment efficiency likewise raises output, but (on impact) it improves the terms of trade (the shock raises investment spending which is biased towards local inputs; hence it raises the relative price of those inputs). As a result, with the combined two types of shock, the terms of trade (and the real exchange rate) are much less cyclical than in standard RBC models that are driven just by TFP shocks (e.g., Backus, Kehoe and Kydland (1994)). ${ }^{8}$

The paper is structured as follows. In section 2, we present the model set-up. In section 3, we derive equilibrium equity and bond portfolios, and we provide empirical support for the key condition that drives equity home bias in the model. In section 4, we provide stylized facts on the dynamics of external asset positions in G7 countries; we present simulation results that show that the model quantitatively captures key dynamic stylized facts.

\section{The model}

There are two (ex-ante) symmetric countries, Home $(H)$ and Foreign $(F)$, each with a representative household. Country $i=H, F$ produces one good using labor and capital. There is trade in goods and in financial assets (stocks and bonds). All markets are perfectly competitive.

\footnotetext{
${ }^{7}$ For other related recent empirical and theoretical analyses of international portfolios and external valuation effects, see e.g. Lewis (1999), Hau and Rey (2004), Siourounis (2004), Kraay and Ventura (2005), Devereux and Saito (2005), Ghironi, Lee and Rebucci (2005), Obstfeld (2006), Kollmann (2006a), and Matsumoto (2007). Evans and Hnatkovska (2005,2007) and Hnatkovska (2005) also discuss a world with capital accumulation and portfolios; those papers do not analyze the hedging logic that is central to our paper, and have a different empirical focus. Cantor and Mark (1988) provided an early theoretical discussion of the role of equity price changes for current accounts, based on a one-good model with equities trade (their model predicts full portfolio diversification).

${ }^{8}$ After the present research was completed, we learnt about a paper by Raffo (2008) that also argues that investment efficiency shocks help to better capture key international business cycle facts.
} 


\subsection{Preferences}

Country $i$ is inhabited by a representative household who lives in periods $t=0,1,2, \ldots$. The household has the following life-time utility function:

$$
E_{0} \sum_{t=0}^{\infty} \beta^{t}\left(\frac{C_{i, t}^{1-\sigma}}{1-\sigma}-\frac{l_{i, t}^{1+\omega}}{1+\omega}\right)
$$

with $\omega>0 . C_{i, t}$ is $i$ 's aggregate consumption in period $t$ and $l_{i, t}$ is labor effort. Like much of the macroeconomics and finance literature, we take the coefficient of relative risk aversion to be greater than unity: $\sigma>1$.

$C_{i, t}$ is a composite good given by:

$$
C_{i, t}=\left[a^{1 / \phi}\left(c_{i, t}^{i}\right)^{(\phi-1) / \phi}+(1-a)^{1 / \phi}\left(c_{j, t}^{i}\right)^{(\phi-1) / \phi}\right]^{\phi /(\phi-1)}, \text { with } j \neq i,
$$

where $c_{j, t}^{i}$ is country $i$ 's consumption of the good produced by country $j$ at date $t . \phi>0$ is the elasticity of substitution between the two goods. In the (symmetric) deterministic steady state, $a$ is the share of consumption spending devoted to the local good. We assume a preference bias for local goods, $\frac{1}{2}<a<1$.

The welfare based consumer price index that corresponds to these preferences is:

$$
P_{i, t}=\left[a\left(p_{i, t}\right)^{1-\phi}+(1-a)\left(p_{j, t}\right)^{1-\phi}\right]^{1 /(1-\phi)}, j \neq i,
$$

where $p_{i, t}$ is the price of good $i$.

\subsection{Technologies and firms}

In period $t$, country $i$ produces $y_{i, t}$ units of good $i$ according to the production function

$$
y_{i, t}=\theta_{i, t}\left(k_{i, t}\right)^{\kappa}\left(l_{i, t}\right)^{1-\kappa}
$$

with $0<\kappa<1 . k_{i, t}$ is the country's stock of capital. Total factor productivity (TFP) $\theta_{i, t}>0$ is an exogenous random variable. The law of motion of the capital stock is:

$$
k_{i, t+1}=(1-\delta) k_{i, t}+\chi_{i, t} I_{i, t}
$$

where $0<\delta<1$ is the depreciation rate of capital. $I_{i, t}$ is gross investment in country $i$ at date $t . \chi_{i, t}>0$ is an exogenous shock to investment efficiency (see Fisher (2002, 2006), Greenwood, Hercowitz and Krusell 
(1997), Justiniano, Primiceri and Tambalotti (2007)). The stochastic properties of the exogenous shocks are symmetric across countries.

In both countries, gross investment is generated using Home and Foreign inputs:

$$
I_{i, t}=\left[a_{I}^{1 / \phi_{I}}\left(i_{i, t}^{i}\right)^{\left(\phi_{I}-1\right) / \phi_{I}}+\left(1-a_{I}\right)^{1 / \phi_{I}}\left(i_{j, t}^{i}\right)^{\left(\phi_{I}-1\right) / \phi_{I}}\right]^{\phi_{I} /\left(\phi_{I}-1\right)}, j \neq i
$$

where $i_{j, t}^{i}$ is the amount of good $j$ used for investment in country $i$. We assume a local bias in investment spending, $\frac{1}{2}<a_{I}<1$. Home bias and the substitution elasticity between domestic and imported inputs may be different for investment and consumption (i.e. we allow for the possibility that $a_{I} \neq a, \phi_{I} \neq \phi$ ). The associated investment price index is:

$$
P_{i, t}^{I}=\left[a_{I}\left(p_{i, t}\right)^{1-\phi_{I}}+\left(1-a_{I}\right)\left(p_{j, t}\right)^{1-\phi_{I}}\right]^{1 /\left(1-\phi_{I}\right)}, j \neq i .
$$

There is a (representative) firm in country $i$ that hires local labor, accumulates physical capital and produces output, using the technology (4),(5); it maximizes the present value of dividend payments, taking prices and wage rates as given.

Due to the Cobb-Douglas technology, a share $1-\kappa$ of output is paid to workers. Thus, the country $i$ wage bill is:

$$
w_{i, t} l_{i, t}=(1-\kappa) p_{i, t} y_{i, t}
$$

where $p_{i, t}$ is the price of the country $i \operatorname{good}$ and $w_{i, t}$ is the country $i$ wage rate. A share $\kappa$ of country $i$ output, net of physical investment spending, is paid as a dividend $d_{i, t}$ to shareholders:

$$
d_{i, t}=\kappa p_{i, t} y_{i, t}-P_{i, t}^{I} I_{i, t}
$$

The firm chooses $I_{i, t}$ to equate the expected future marginal gain of investment to the marginal cost. This implies the following first-order condition:

$$
1=E_{t} \varrho_{t, t+1}^{i} \frac{\chi_{i, t}}{P_{i, t}^{I}}\left[p_{i, t+1} \theta_{i, t+1} \kappa k_{i, t+1}^{\kappa-1} l_{i, t+1}^{1-\kappa}+(1-\delta) \frac{P_{i, t+1}^{I}}{\chi_{i, t+1}}\right]
$$

where $\varrho_{t, t+1}^{i} \equiv \beta\left(C_{i, t+1} / C_{i, t}\right)^{-\sigma}\left(P_{i, t} / P_{i, t+1}\right)$ is a pricing kernel used at date $t$ to value date $t+1$ payoffs. Note that we assume that $\varrho_{t, t+1}^{i}$ equals the intertemporal marginal rate of substitution of the country $i$ household. ${ }^{9}$ The firm chooses the Home and Foreign investment inputs $i_{H, t}^{i}, i_{F, t}^{i}$ that minimize the cost

\footnotetext{
${ }^{9}$ When the Home and Foreign households' Euler equations for Home/Foreign stocks shown below hold (see (14)), then (10) holds also for a pricing kernel that equals the intertemporal marginal rate of substitution of the country $j \neq i$ household.
} 
of generating $I_{i, t}$. That cost minimization problem has the following first-order conditions:

$$
i_{i, t}^{i}=a_{I}\left(\frac{p_{i, t}}{P_{i, t}^{I}}\right)^{-\phi_{I}} I_{i, t}, \quad i_{j, t}^{i}=\left(1-a_{I}\right)\left(\frac{p_{j, t}}{P_{i, t}^{I}}\right)^{-\phi_{L}} I_{i, t}, j \neq i .
$$

\subsection{Financial markets, household decisions, market clearing}

There is international trade in stocks and bonds. The country $i$ firm issues a stock that represents a claim to its stream of dividends $\left\{d_{i, t}\right\}$. The supply of each share is normalized at unity. There is a bond denominated in the Home good, and a bond denominated in the Foreign good; buying one unit of the Home (Foreign) bond in period $t$ gives one unit of the Home (Foreign) good in all future periods. Both bonds are in zero net supply. Each household fully owns the local stock, at birth, and has zero initial foreign assets. ${ }^{10} \quad$ Let $S_{j, t+1}^{i}$ denote the number of shares of stock $j$ held by the country $i$ household at the end of period $t$, while $b_{j, t+1}^{i}$ represents claims held by $i$ (at the end of $t$ ) to future unconditional payments of good $j$. At date $t$, the country $i$ household faces the following budget constraint:

$$
\begin{aligned}
& P_{i, t} C_{i, t}+p_{i, t}^{S} S_{i, t+1}^{i}+p_{j, t}^{S} S_{j, t+1}^{i}+p_{i, t}^{b} b_{i, t+1}^{i}+p_{j, t}^{b} b_{j, t+1}^{i} \\
= & w_{i, t} l_{i, t}+\left(p_{i, t}^{S}+d_{i, t}\right) S_{i, t}^{i}+\left(p_{j, t}^{S}+d_{j, t}\right) S_{j, t}^{i}+\left(p_{i, t}^{b}+p_{i, t}\right) b_{i, t}^{i}+\left(p_{j, t}^{b}+p_{j, t}\right) b_{j, t}^{i}, \quad j \neq i,
\end{aligned}
$$

where $p_{i, t}^{S}$ is the price of stock $i$ and $p_{i, t}^{b}$ is the price of the good- $i$ bond.

Each household selects portfolios, consumptions and labor supplies that maximize her life-time utility (1) subject to her budget constraint (12) for $t \geq 0$. Ruling out Ponzi-schemes, the following equations are first-order conditions of household $i$ 's decision problem:

$$
\begin{gathered}
c_{i, t}^{i}=a\left(\frac{p_{i, t}}{P_{i, t}}\right)^{-\phi} C_{i, t}, \quad c_{j, t}^{i}=(1-a)\left(\frac{p_{j, t}}{P_{i, t}}\right)^{-\phi} C_{i, t}, \quad l_{i, t}^{\omega}=\left(\frac{w_{i, t}}{P_{i, t}}\right) C_{i, t}-\sigma \\
1=E_{t} \varrho_{t, t+1}^{i} R_{j, t+1}^{S}, 1=E_{t} \varrho_{t, t+1}^{i} R_{j, t+1}^{b} \quad \text { for } j=H, F \\
\text { with } R_{j, t+1}^{S} \equiv \frac{p_{j, t+1}^{S}+d_{j, t+1}}{p_{j, t}^{S}}, \quad R_{j, t+1}^{b} \equiv \frac{p_{j, t+1}^{b}+p_{j, t+1}}{p_{j, t}^{b}} .
\end{gathered}
$$

$R_{j, t+1}^{S}$ and $R_{j, t+1}^{b}$ are the gross returns of stock $j$, and of the good- $j$ bond, respectively (between periods $t$ and $t+1)$. (13) represents the optimal allocation of consumption spending across goods, and

\footnotetext{
${ }^{10}$ We also assume that initial capital stocks and productivities are identical across countries: $K_{H, 0}=K_{F, 0}, \theta_{H, 0}=\theta_{F, 0}$, $\chi_{H, 0}=\chi_{F, 0}$. This ensures that both countries have equal wealth at birth, and preserves the (ex ante) symmetry of the two countries.
} 
the labor supply decision. (14) shows Euler equations with respect to the two stocks and the Home and Foreign good bonds.

Market-clearing in goods and asset markets requires:

$$
\begin{gathered}
c_{H, t}^{H}+c_{H, t}^{F}+i_{H, t}^{H}+i_{H, t}^{F}=y_{H, t}, \quad c_{F, t}^{F}+c_{F, t}^{H}+i_{F, t}^{F}+i_{F, t}^{H}=y_{F, t}, \\
S_{H, t}^{H}+S_{H, t}^{F}=S_{F, t}^{F}+S_{F, t}^{H}=1, \quad b_{H, t}^{H}+b_{H, t}^{F}=b_{F, t}^{F}+b_{F, t}^{H}=0 .
\end{gathered}
$$

\subsection{Relative consumption and investment demand}

Subsequent discussions will use the following properties of consumption and investment demand. The first-order condition for consumption (13) implies:

$$
c_{H, t}^{H}+c_{H, t}^{F}=p_{H, t}^{-\phi}\left[a C_{H, t} P_{H, t}^{\phi}+(1-a) C_{F, t} P_{F, t}^{\phi}\right], \quad c_{F, t}^{F}+c_{F, t}^{H}=p_{F, t}^{-\phi}\left[a C_{F, t} P_{F, t}^{\phi}+(1-a) C_{H, t} P_{H, t}^{\phi}\right]
$$

Taking the ratio of these expressions gives:

$$
y_{C, t} \equiv \frac{c_{H, t}^{H}+c_{H, t}^{F}}{c_{F, t}^{F}+c_{F, t}^{H}}=q_{t}^{-\phi} \Omega_{a}\left[\left(\frac{P_{F, t}}{P_{H, t}}\right)^{\phi} \frac{C_{F, t}}{C_{H, t}}\right], \quad \text { with } \quad \Omega_{z}(x) \equiv \frac{1+x\left(\frac{1-z}{z}\right)}{x+\left(\frac{1-z}{z}\right)} .
$$

$y_{C, t}$ is the ratio of world consumption of Home goods over world consumption of Foreign goods, while $q_{t} \equiv p_{H, t} / p_{F, t}$ denotes the country $\mathrm{H}$ terms of trade.

The ratio of world demand for Home vs. Foreign goods used for physical investment $y_{I, t} \equiv \frac{i_{H, t}^{H}+i_{H, t}^{F}}{i_{F, t}^{F}+i_{F, t}^{H}}$ can similarly be expressed as:

$$
y_{I, t} \equiv q_{t}^{-\phi_{I}} \Omega_{a_{I}}\left[\left(\frac{P_{F, t}^{I}}{P_{H, t}^{I}}\right)^{\phi_{I}} \frac{I_{F, t}}{I_{H, t}}\right]
$$

\section{Characterization of (steady state) equilibrium portfolios}

Equilibrium portfolio holdings chosen at date $t\left(S_{i, t+1}^{i}, S_{j, t+1}^{i}, b_{i, t+1}^{i}, b_{j, t+1}^{i}\right)$ are functions of predetermined state variables, and of exogenous shocks at $t$. Devereux and Sutherland (2006a,b) show how to compute Taylor expansion of the portfolio decision rules, in the neighborhood of the deterministic steady state. In this Section, we provide closed form solutions for the Home/Foreign 'zero-order portfolio' (denoted by variables without time subscripts) $S_{i}^{i}, S_{j}^{i}, b_{i}^{i}, b_{j}^{i}$, i.e. portfolio decision rules evaluated at steady 
state values of state variables. That portfolio can be determined by linearizing the model around its steady state. ${ }^{11}$

\subsection{Linearization of the model}

Henceforth, variables without a time subscript refer to the steady state. $\widehat{z_{t}} \equiv\left(z_{t}-z\right) / z$ denotes the relative deviation of a variable $z_{t}$ from its steady state value $z$.

Below we find a zero-order portfolio such that the ratio of Home to Foreign marginal utilities of aggregate consumption, $C_{H, t}^{-\sigma} / C_{F, t}^{-\sigma}$, is equated to the consumption-based real exchange rate, $R E R_{t} \equiv$ $\frac{P_{H, t}}{P_{F, t}}$, up to first order:

$$
-\sigma\left(\widehat{C_{H, t}}-\widehat{C_{F, t}}\right)=\widehat{R E R_{t}}
$$

This is a linearized version of a risk sharing condition that holds under complete markets (Backus and Smith (1993), Kollmann (1991, 1995)). Up to first order, the asset structure here (four assets, in a world with four exogenous shocks) is thus (effectively) complete. ${ }^{12}$

It follows from the definition of Home and Foreign CPI indices (see (3)) that

$$
\widehat{R E R_{t}}=\widehat{P_{H, t}}-\widehat{P_{F, t}}=(2 a-1) \widehat{q_{t}} .
$$

Due to consumption home bias $\left(a>\frac{1}{2}\right)$, an improvement of the Home terms of trade generates an appreciation of the Home real exchange rate.

When (20) holds, then the relative world consumption demand for the Home good obeys (from (18)):

$$
\widehat{y_{C, t}}=-\left[\phi\left(1-(2 a-1)^{2}\right)+(2 a-1)^{2} \frac{1}{\sigma}\right] \widehat{q_{t}} \equiv-\lambda \widehat{q_{t}}
$$

where $\lambda \equiv \phi\left(1-(2 a-1)^{2}\right)+\frac{(2 a-1)^{2}}{\sigma}$. Note that $\lambda>0 \quad\left(\right.$ as $1 / 2<a<1$ implies $\left.0<1-(2 a-1)^{2}\right)$. Thus, an improvement in the Home terms of trade lowers worldwide relative consumption of the Home good.

\footnotetext{
${ }^{11}$ Devereux and Sutherland $(2006 \mathrm{a}, \mathrm{b})$ show that the zero-order equilibrium portfolio has to satisfy a second-order accurate approximation of household Euler equations, expressed in 'relative' form: $0=E_{t} \varrho_{t, t+1} r_{t+1}^{X}$, where $\varrho_{t, t+1} \equiv \varrho_{t, t+1}^{H}-\varrho_{t, t+1}^{F}$ is the 'relative' IMRS of the two houseolds, while $r_{t+1}^{X} \equiv\left(R_{H, t+1}^{S}-R_{H, t+1}^{b}, R_{F, t+1}^{S}-R_{H, t+1}^{b}, R_{F, t+1}^{b}-R_{H, t+1}^{b}\right)$ is a vector of excess returns. As $\varrho=r^{X}=0$ in steady state, a second-order accurate approximation is given by $0=E_{t}\left(\varrho_{t, t+1}\right)^{(1)}\left(r_{t+1}^{X}\right)^{(1)}$, where $\left(\varrho_{t, t+1}\right)^{(1)}$ and $\left(r_{t+1}^{X}\right)^{(1)}$ are first-order accurate. The zero-order portfolio discusses below satisfies a linearized risk sharing condition ( $\mathrm{see}(20))$ that entails that $\left(\varrho_{t, t+1}\right)^{(1)}=0$; thus, $0=E_{t} \varrho_{t, t+1} r_{t+1}^{X}$ holds to second-order.

${ }^{12}$ Using the apparatus of Devereux and Sutherland (2006a,b) we confirmed for the model calibration below (and for all of many other calibrations with which we experimented) that the zero-order equilibrium portfolio is unique; there is no zero-order equilibrium portfolio for which the risk sharing condition (20) does not hold, to first order.
} 
Linearization of (19) and (7) shows that relative world investment demand for the Home good, $y_{I, t}$, obeys:

$$
\widehat{y_{I, t}}=-\phi_{I}\left(1-\left(2 a_{I}-1\right)^{2}\right) \widehat{q_{t}}+\left(2 a_{I}-1\right) \widehat{I}_{t},
$$

where $I_{t} \equiv I_{H, t} / I_{F, t}$ is relative real aggregate investment. Holding constant the terms of trade, the relative demand for Home investment goods, $y_{I, t}$, increases with relative real investment in the Home country, $I_{t}$, since Home aggregate investment is biased towards the Home good $\left(a_{I}>\frac{1}{2}\right)$.

The market clearing condition for goods (16) implies:

$$
(1-\Lambda) \widehat{y_{C, t}}+\Lambda \widehat{y_{I, t}}=\widehat{y_{t}}
$$

where $y_{t} \equiv Y_{H, t} / Y_{F, t}$ is relative Home output, while $\Lambda \equiv \frac{P_{H}^{I} I_{H}}{p_{H} y_{H}}=\frac{P_{F}^{I} I_{F}}{p_{F} y_{F}}$ is the steady state investment/GDP ratio. ${ }^{13}$

Substituting (22) and (23) into (24) gives:

$$
\widehat{y_{t}}=-\lambda^{*} \widehat{q_{t}}+\Lambda\left(2 a_{I}-1\right) \widehat{I_{t}}
$$

where $\lambda^{*}=(1-\Lambda) \lambda+\Lambda \phi_{I}\left(1-\left(2 a_{I}-1\right)^{2}\right)>0 . \quad 14$

Not surprisingly, Home terms of trade worsen when the relative supply of Home goods increases, for a given amount of relative Home country investment. Home terms of trade improve when Home investment rises (due to local bias in investment spending), for a given value of the relative Home/Foreign output.

\section{$3.2 \quad$ Zero-order portfolios}

Ex-ante symmetry implies that the zero-order portfolios have to satisfy these conditions: $S \equiv S_{H}^{H}=$ $S_{F}^{F}=1-S_{H}^{F}=1-S_{F}^{H} ; \quad b \equiv b_{H}^{H}=b_{F}^{F}=-b_{H}^{F}=-b_{F}^{H}$. The pair $(S, b)$ thus describes the (zero-order) equilibrium portfolio. Note that $S$ denotes a country's holdings of local stock, while $b$ denotes its holdings of bonds denominated in the local good. There is equity home bias when $S>\frac{1}{2} . \quad b>0$ means that a country is long in local-good bonds (and short in foreign-good bonds).

\footnotetext{
${ }^{13}$ Note that, because of symmetry, $P_{H}^{I} / p_{H}=P_{F}^{I} / p_{F}=1, I_{H}=I_{F}, y_{H}=y_{F}$. The steady state investment/GDP ratio is given by $\Lambda=\kappa /[(1 / \delta)(1-\beta) / \beta+1]$. Thus $\varkappa-\Lambda>0$. This ensures that dividends are strictly positive in steady state.

${ }^{14}$ When $\phi_{I}=\phi$ and $a_{I}=a$ then $\lambda^{*}=\phi\left(1-(2 a-1)^{2}\right)+\frac{1-\Lambda}{\sigma}(2 a-1)^{2}$.
} 
We now show that there exists a unique portfolio $(S, b)$ that satisfies the following 'static' budget constraint, for consumptions that are consistent with the linearized risk sharing condition (20):

$$
P_{i, t} C_{i, t}=w_{i, t} l_{i, t}+S d_{i, t}+(1-S) d_{j, t}+b\left(p_{i, t}-p_{j, t}\right), \text { for } i=H, F
$$

According to this constraint, country $i$ consumption spending at date $t$ equals date $t$ wage income, $w_{i, t} l_{i, t}$, plus the financial income generated by the zero-order portfolio $(S, b)$. We show in the Appendix that when this 'static' budget constraint holds, then the period-by-period budget constraint (12) is likewise satisfied, up to first-order. We here focus on the 'static' budget constraint, as it greatly simplifies the analysis.

Subtracting the 'static' budget constraint of country $F$ from that of country $H$ gives: $P_{H, t} C_{H, t}-$ $P_{F, t} C_{F, t}=\left(w_{H, t} l_{H, t}-w_{F, t} l_{F, t}\right)+(2 S-1)\left(d_{H, t}-d_{F, t}\right)+2 b\left(p_{H, t}-p_{F, t}\right)$. Linearizing this yields:

$$
(1-\Lambda)\left(\widehat{P_{H, t} C_{H, t}}-\widehat{P_{F, t} C_{F, t}}\right)=(1-\Lambda)\left(1-\frac{1}{\sigma}\right) \underbrace{(2 a-1){\widehat{q_{t}}}^{2}}_{\widehat{R E R}_{t}}=(1-\kappa) \widehat{w_{t} l_{t}}+(2 S-1)(\kappa-\Lambda) \widehat{d_{t}}+2 \widetilde{b} \widehat{q_{t}}, \quad \widetilde{b} \equiv b / y_{H},
$$

where $\widehat{w_{t} l_{t}} \equiv \widehat{w_{H, t} l_{H, t}}-\widehat{w_{F, t} l_{F, t}}$ denotes relative Home labor income, while $\widehat{d_{t}} \equiv \widehat{d_{H, t}}-\widehat{d_{F, t}}$ is the relative Home dividend, and $\widetilde{b}$ represents holdings of local-good bonds, divided by steady state GDP.

The first equality in (27) follows from the linearized risk-sharing condition (20); it shows the efficient reaction of relative consumption spending to a change of the welfare based real exchange rate. This reaction depends on the coefficient of relative risk aversion. A shock that appreciates the real exchange rate of country $H$, induces an increase in country $H$ relative consumption spending when $\sigma>1$ (as assumed here). (20) shows that when the Home real exchange rate appreciates by $1 \%$, then relative aggregate country $H$ consumption $\left(\frac{C_{H}}{C_{F}}\right)$ decreases by $1 / \sigma \%$. Hence, relative country $H$ consumption spending $\left(\frac{P_{H} C_{H}}{P_{F} C_{F}}\right)$ increases by $\left(1-\frac{1}{\sigma}\right) \%$.

The expression to the right in (27) shows the change in country $H$ income (relative to the income of $F$ ) necessary to finance the efficient consumption (up to first order). Given $\sigma>1$, the efficient portfolio has to be such that a real appreciation is associated with an increase in relative Home income.

Since labor income is a constant share of output (see $(8))$, relative labor income $\left(\widehat{w}_{t} l_{t}\right)$ is given by: $\widehat{w_{t} l_{t}}=\widehat{q_{t}}+\widehat{y_{t}}$. (9) and (7) imply that the relative dividend $\left(\widehat{d_{t}}\right)$ is given by:

$$
(\kappa-\Lambda) \widehat{d}_{t}=\kappa\left(\widehat{q_{t}}+\widehat{y_{t}}\right)-\Lambda\left(\widehat{P_{H, t}^{I} I_{H, t}}-\widehat{P_{F, t}^{I} I_{F, t}}\right)=\kappa\left(\widehat{q_{t}}+\widehat{y_{t}}\right)-\Lambda\left(\left(2 a_{I}-1\right) \widehat{q_{t}}+\widehat{I}_{t}\right) .
$$


Substituting (28) into (27) gives:

$$
(1-\Lambda)\left(1-\frac{1}{\sigma}\right)(2 a-1) \widehat{q_{t}}=(1-\kappa)\left(\widehat{q_{t}}+\widehat{y_{t}}\right)+(2 S-1)\left\{\kappa\left(\widehat{q_{t}}+\widehat{y_{t}}\right)-\Lambda\left(\left(2 a_{I}-1\right) \widehat{q_{t}}+\widehat{I_{t}}\right)\right\}+2 \widetilde{b} \widehat{q_{t}}
$$

Using (25), we can express (29) as:

$$
(1-\Lambda)\left(1-\frac{1}{\sigma}\right)(2 a-1) \widehat{q_{t}}=[(1-\kappa)+\kappa(2 S-1)]\left(\left(1-\lambda^{*}\right) \widehat{q_{t}}+\Lambda\left(2 a_{I}-1\right) \widehat{I}_{t}\right)-\Lambda(2 S-1)\left[\left(2 a_{I}-1\right) \widehat{q}_{t}+\widehat{I}_{t}\right]+2 \widetilde{b} \widehat{q}_{t} .
$$

The asset structure supports the full risk sharing condition (20), up to first-order, if (30) holds for all realizations of the two (relative) exogenous shocks $\left(\widehat{\theta}_{t}, \widehat{\chi}_{t}\right)$. Note that the persistence of shocks and their correlation do not matter for the (zero-order) equilibrium portfolio (however it is necessary that the shocks are not perfectly correlated). In fact, to solve for that portfolio, we do not have to solve for output and investment, as a unique pair of terms of trade and relative real investment $\left(\widehat{q}_{t}, \widehat{I}_{t}\right)$ is associated with each realizations of $\left(\widehat{\theta}_{t}, \widehat{\chi}_{t}\right)$.

The following portfolio $(S, \widetilde{b})$ ensures that $(30)$ holds for arbitrary realizations of $\left(\widehat{q}_{t}, \widehat{I}_{t}\right)$ :

$$
\begin{aligned}
S & =\frac{1}{2}\left[1+\frac{\left(2 a_{I}-1\right)(1-\kappa)}{1-\left(2 a_{I}-1\right) \kappa}\right]>\frac{1}{2} \\
\widetilde{b} & =\frac{1}{2}\left[(1-\Lambda)\left(1-\frac{1}{\sigma}\right)(2 a-1)+\frac{(1-\kappa)\left[\lambda^{*}-1+\Lambda\left(2 a_{I}-1\right)^{2}\right]}{1-\left(2 a_{I}-1\right) \kappa}\right]
\end{aligned}
$$

Thus, the model generates equity home bias, $S>1 / 2$. Interestingly, the equity portfolio is independent of preference parameters; in particular, $S$ is independent of the substitution elasticity between Home and Foreign goods, and thus of the strength of the response of the terms of trade to shocks. ${ }^{15}$ The equity portfolio solely depends on the local bias in investment spending $\left(a_{I}\right)$ and the capital share $(\kappa)$; equity home bias is increasing in the local spending bias-this prediction is strongly supported by the data (see Heathcote and Perri (2007) and Collard, Dellas, Diba and Stockman (2007)).

By contrast, in general equilibrium models with just trade in stocks (no bonds), the equity portfolio exhibits strong sensitivity with respect to the substitution elasticity between local and imported goods (e.g., Kollmann (2006b), Coeurdacier (2005) and Heathcote and Perri (2007)). ${ }^{16}$

\footnotetext{
${ }^{15}$ However it is necessary that good are imperfect substitutes so that the terms of trade show a non-zero response to shocks.

${ }^{16}$ In those models, the asset structure cannot support the efficient allocation when Home and Foreign dividends are colinear, which occurs for a value of the substitution elasticity roughly located between 1 and 2 ; for substitution elasticities just below or above the critical value, the local equity share takes extremely large positive or negative values.
} 
Note that, in the model here, the bond portfolio does depend on the substitution elasticities $\phi, \phi_{I}$ (via $\left.\lambda^{*}\right)$ and on risk aversion $(\sigma)$; however this dependence is 'smooth': in particular, $\widetilde{b}$ is a linear function of $\phi$ and $\phi_{I} \cdot{ }^{17}$ Little is known empirically about the currency denomination of external bond holdings (the fact that countries can easily alter the effective currency composition by taking net positions in the forward currency market further complicates the picture). Depending on preference parameters, the model can generate positive or negative foreign currency exposure on the bond portfolio. The country will go short in the local-good bond $(\widetilde{b}<0)$ when $\phi$ is sufficiently low (roughly below unity). ${ }^{18}$

\section{The hedging roles of bonds and stocks}

We now show that the bond portfolio hedges terms of trade risk - as preference parameters affect the response of relative consumption to terms of trade changes, bond holdings depend on those preference parameters. Equities are used to hedge fluctuations in relative wages and dividends that are orthogonal to the terms of trade. The comovement of relative wages and dividends, at constant terms of trade, depends on $a_{I}$ and $\kappa$, but not on preference parameters - which explains why the equilibrium value of $S$ is a function of $a_{I}$ and $\kappa .{ }^{19}$

Assume a combination of exogenous shocks $\left(\widehat{\theta_{t}}, \widehat{\chi}_{t}\right)$ that raises relative country $H$ real investment spending, without altering the terms of trade: $\widehat{I}_{t}>0, \widehat{q}_{t}=0$. From (25), we know that this combination of shocks raises $H$ relative output $\widehat{y_{t}}$, due to local bias in investment spending $\left(a_{I}>1 / 2\right): \widehat{y_{t}}=$ $\Lambda\left(2 a_{I}-1\right) \widehat{I}_{t}>0$, when $\widehat{q_{t}}=0$. As the real exchange rate is unaffected when $\widehat{q}_{t}=0$ (see $\left.(21)\right)$, efficient risk sharing requires that countries' relative consumption spending remains unchanged. Hence, the efficient portfolio has to be such that the countries' relative income too is unaffected. From (29) it can be seen that this requires that:

$$
0=(1-\kappa) \widehat{y_{t}}+(2 S-1)\left\{\kappa \widehat{y_{t}}-\Lambda \widehat{I_{t}}\right\}
$$

$(1-\kappa) \widehat{y_{t}}$ and $\left\{\kappa \widehat{y_{t}}-\Lambda \widehat{I}_{t}\right\}$ respectively represent relative labor income of country $H$ and the relative

\footnotetext{
${ }^{17}$ See Coeurdacier, Kollmann and Martin (2007) and Coeurdacier and Gourinchas (2008) for a similar result.

${ }^{18}$ When $\phi$ is low, then terms of trade respond strongly to shocks; an improvement in the Home terms of trade (induced by a fall in Home TFP and/or an increase in Home investment efficiency) increases Home relative wage plus dividend income (due to the strong terms of trade change); risk sharing requires to compensate this relative income effect by shorting the local good bond (when $\widetilde{b}<0$, a terms of trade improvement lowers the net bond income received by Home).

${ }^{19}$ Coeurdacier and Gourinchas (2008) provide a general discussion of conditions under which international equity portfolios are independent of preferences; they show that an important condition is that bonds exist whose pay-offs perfectly track real exchange rate movements.
} 
dividend of stock $H$, for $\widehat{q_{t}}=0$. Note that $\kappa \widehat{y_{t}}-\Lambda \widehat{I}_{t}=\left[\kappa\left(2 a_{I}-1\right)-1\right] \Lambda \widehat{I}_{t}$ when $\widehat{y_{t}}=\Lambda\left(2 a_{I}-1\right) \widehat{I}_{t}$. Thus, $\kappa \widehat{y_{t}}-\Lambda \widehat{I}_{t}<0$ when $\widehat{I}_{t}>0, \widehat{q_{t}}=0$. In other terms, a combination of shocks that raises $H$ relative investment without affecting the terms of trade induces a rise in $H$ 's relative wage income, and a fall in the relative dividend of stock $H$. This makes holding local equity attractive: $S>1 / 2$ is needed to ensure that (33) holds. ${ }^{20}$

Once shocks that do not affect the terms of trade have been hedged by holding local equity, the remaining risk (changes in output/investment that are associated with terms of trade changes) can be hedged (up to a linear approximation) using the bond portfolio; this is so because terms of trade movements are perfectly correlated with the difference between the pay-offs of Home and Foreign good bonds.

\section{Comparison with Heathcote and Perri (2007)}

Our equity portfolio (31) corresponds to that obtained by Heathcote and Perri (2007) [HP] for a special case of their model where $\sigma=\phi=1$. HP consider a two-country world with capital accumulation; their model assumes just trade in stocks (no bonds), and just TFP shocks. In that model, the equity portfolio is sensitive to slight changes in risk aversion or the substitution elasticity across goods: when $\sigma$ or $\phi$ are only slightly larger than unity, their model generates equity foreign bias: households short the home stock. ${ }^{21}$ Here we have shown that that sensitivity of portfolio choices disappears once we allow for trade in bonds, and a shock to investment efficiency. This robustness is due to the fact that, in our model, terms of trade risk is hedged by the bond portfolio. This result is important, as there is considerable uncertainty regarding the value of the substitution elasticity between domestic and foreign goods: estimates from aggregate macro data are scattered around unity, but estimates from sectoral trade data are above 4 (see Imbs and Méjean (2008) for a detailed discussion).

The reason why the HP model delivers equity home bias when $\sigma=\phi=1$ is that, for that parameterization, the two countries' efficient relative consumption spending is constant, while a country's relative wage income is (perfectly) negatively correlated with the relative dividend of the stock issued by the country $\left(\operatorname{Corr}\left(\widehat{w_{t} l_{t}}, \widehat{d}_{t}\right)<0\right)$, which implies that local equity is a good hedge for labor income risk. As documented below, the correlation between relative wage income $\left({\widehat{w_{t} l}}_{t}\right)$ and the relative dividend $\left(\widehat{d}_{t}\right)$ is

\footnotetext{
${ }^{20}$ To derive the value of $\mathrm{S}$ shown in (31), one can substitute $\widehat{y_{t}}=\Lambda\left(2 a_{I}-1\right) \widehat{I}_{t}$ into (33); the only value of $S$ for which the resulting expression holds for arbitrary $\widehat{I_{t}}$ is given by (31).

${ }^{21}$ Castello (2007) considers a model of portfolio choice with capital accumulation close to HP; in her model too, equity portfolios are highly sensitive to preference parameters.
} 
positive, for G7 countries. Thus, the key mechanism that generates equity home bias in the HP model is rejected empirically.

\subsection{The role of the correlation between relative wage incomes and relative dividends}

In our model, the unconditional correlation $\operatorname{Corr}\left(\widehat{w_{t} l_{t}}, \widehat{d_{t}}\right)$ per se is irrelevant for the equilibrium equity portfolio. What matters is the correlation between the components of $\widehat{w_{t} l_{t}}$ and $\widehat{d_{t}}$ that are orthogonal to the terms of trade, $\widehat{q}_{t}$ : there is equity home bias when that correlation is negative. To see this, project equation $(27)$ on $\widehat{q_{t}}$. This gives:

$$
(1-\Lambda)\left(1-\frac{1}{\sigma}\right)(2 a-1) \widehat{q_{t}}=(1-\kappa) P\left[\widehat{w_{t} l_{t}} \mid \widehat{q_{t}}\right]+(2 S-1)(\kappa-\Lambda) P\left[\widehat{d}_{t} \mid \widehat{q_{t}}\right]+2 \widetilde{b} \widehat{q_{t}},
$$

where $P\left[\widehat{w_{t} l_{t}} \mid \widehat{q_{t}}\right]$ is the (linear) projection of $\widehat{w_{t} l_{t}}$ on $\widehat{q_{t}}$. (NB $\left.\widehat{q_{t}}=P\left[\widehat{q}_{t} \mid \widehat{q_{t}}\right].\right)$ Subtracting (34) from (27) gives:

$$
0=(1-\kappa)\left\{\widehat{w_{t} l_{t}}-P\left[\widehat{w_{t} l_{t}} \mid \widehat{q_{t}}\right]\right\}+(2 S-1)(\kappa-\Lambda)\left\{\widehat{d_{t}}-P\left[\widehat{d}_{t} \mid \widehat{q}_{t}\right]\right\}
$$

Thus, the equity portfolio has to hedge the components of $\widehat{w_{t} l_{t}}$ and $\widehat{d}_{t}$ that are orthogonal to the terms of trade $\widehat{q_{t}}$. (35) implies that

$$
S=\frac{1}{2}-\frac{1}{2} \frac{1-\kappa}{\kappa-\Lambda} \frac{\operatorname{Cov}_{\widehat{q}}\left(\widehat{w_{t} l_{t}}, \widehat{d}_{t}\right)}{\operatorname{Var}_{\widehat{q}}\left(\widehat{d}_{t}\right)},
$$

with $\operatorname{Cov}_{\widehat{q}}\left(\widehat{w_{t} l_{t}}, \widehat{d_{t}}\right) \equiv E\left\{\widehat{w_{t} l_{t}}-P\left[\widehat{w_{t} l_{t}} \mid \widehat{q}_{t}\right]\right\}\left\{\widehat{d}_{t}-P\left[\widehat{d}_{t} \mid \widehat{q}_{t}\right\}, \operatorname{Var}_{\widehat{q}}\left(\widehat{d}_{t}\right) \equiv E\left\{\widehat{d_{t}}-P\left[\widehat{d}_{t} \mid \widehat{q}_{t}\right]\right\}^{2}\right.$. ${ }^{22} \quad$ Hence there is equity home bias if and only if $\operatorname{Cov}_{\widehat{q}}\left(\widehat{w_{t} l_{t}}, \widehat{d}_{t}\right)<0 .{ }^{23}$ In the model here, $\operatorname{Cov}_{\widehat{q}}\left(\widehat{w_{t} l_{t}}, \widehat{d}_{t}\right)=$ $(\kappa-\Lambda)\left(2 a_{I}-1\right) /\left[\left(\kappa\left(2 a_{I}-1\right)-1\right)\right]<0$. Empirically, $\operatorname{Cov}_{\widehat{q}}\left(\widehat{w_{t} l_{t}}, \widehat{d}_{t}\right)<0$, for G7 countries, as documented below.

We here have expressed the equilibrium equity portfolio as a function of the covariance between income flows (wages and dividends). As shown in the Appendix, the equity home bias can equivalently be expressed as a function of the covariance between the components of relative (Home vs. Foreign) human capital returns and (relative) equity returns that are orthogonal to (relative) bond returns: there is equity home bias when that covariance is negative. ${ }^{24}$

\footnotetext{
${ }^{22}$ To see this, multiply (35) by $\left\{\widehat{d}_{t}-P\left[\widehat{d}_{t} \mid \widehat{q_{t}}\right]\right\}$ and take expectations; solving the resulting equation for $S$ gives (36).

${ }^{23}$ Note that the steady state investment/GDP ratio is $\Lambda=\kappa /[(1 / \delta)(1-\beta) / \beta+1]$. Hence, $\kappa>\Lambda$. This ensures that dividends are strictly positive in steady state.

${ }^{24}$ See Coeurdacier and Gourinchas (2008) for preliminary evidence that supports that equity home bias condition in terms of returns.
} 
Note also that $(1-\kappa) P\left[\widehat{w_{t} l_{t}} \mid \widehat{q}_{t}\right]+(2 S-1)(\kappa-\Lambda) P\left[\widehat{d}_{t} \mid \widehat{q}_{t}\right]=\gamma \widehat{q_{t}}$ for some coefficient $\gamma$. Hence, (34) can be expressed as: $(1-\Lambda)\left(1-\frac{1}{\sigma}\right)(2 a-1) \widehat{q_{t}}=\gamma \widehat{q_{t}}+2 \widetilde{b} \widehat{q_{t}}$. The bond position is set at the value for which this condition holds for any realization of $\widehat{q_{t}}: \widetilde{b}=\frac{1}{2}\left[(1-\Lambda)\left(1-\frac{1}{\sigma}\right)(2 a-1)-\gamma\right]$. Thus, the optimal bond position ensures that terms of trade fluctuations induce movements in the two countries' relative incomes (given the optimal equity portfolio) that track optimal relative consumption spending.

\section{Equilibrium equity portfolios for countries of different size}

In order to permit empirical analysis of the determinants of equity home bias, we now briefly consider a two-country model with countries of unequal size, due to different steady state TFP (and/or population). Assume that all preference and technology parameters are the same across countries. Then $S_{i}^{i}$ is given by:

$$
S_{i}^{i}=\mu_{i}-\left(1-\mu_{i}\right) \frac{1-\kappa}{\kappa-\Lambda} \frac{\operatorname{Cov}_{\widehat{q}}\left(\widehat{w_{t} l_{t}}, \widehat{d}_{t}\right)}{\operatorname{Var}_{\widehat{q}}\left(\widehat{d}_{t}\right)} .
$$

were $\mu_{i} \equiv p_{i} y_{i} /\left(p_{H} y_{H}+p_{F} y_{F}\right)$ is the (steady state) share of country i's GDP in world GDP. ${ }^{25}$ Again, there is equity home bias $\left(S_{i}^{i}>\mu_{i}\right)$ when $\operatorname{Cov}_{\widehat{q}}\left(\widehat{w_{t} l_{t}}, \widehat{d}_{t}\right)<0$. We now show that this condition holds empirically.

\section{Empirical evidence on the correlation between relative wage income and relative divi-} dends in G7 countries

For each G7 country, we obtained annual time series on aggregate nominal wage incomes of domestic households, and on profits of domestic firms. ${ }^{26}$ An empirical counterpart to the 'dividend' of the country $i$ firm $d_{i}$ is constructed by subtracting gross investment spending from profits. We divide each country's nominal wage income (dividend) by total wage income (dividend) in the remaining G7 countries (using nominal exchange rates). We log and linearly de-trend the resulting series to construct the relative wage income and dividend variables $\widehat{w_{t} l_{t}}$ and $\widehat{d_{t}}$. The empirical correlations $\operatorname{Corr}\left(\widehat{w_{t} l_{t}}, \widehat{d_{t}}\right)$ are given in Table 1 (sample period: 1984-2004). For six of the G7 countries, the correlation between relative wage income and the relative dividend is positive, and significantly different from zero.

Table 1 also shows estimates of $\operatorname{Corr}_{\widehat{q}}\left(\widehat{w}_{t} l_{t}, \widehat{d}_{t}\right)$. In the model, the terms of trade correspond to the relative price of Home-produced and Foreign-produced goods. Our empirical measure of the country $i$

\footnotetext{
${ }^{25}$ When $\kappa, \delta, \beta$ are identical across countries, then the steady state investment spending/GDP ratio $\Lambda$ is likewise identical.

${ }^{26}$ Series: 'Compensation of employees' and 'Gross operating surplus and gross mixed income' from OECD Annual National Accounts. Source of other data used in this Section: OECD Annual National Accounts and International Financial Statistics.
} 
terms of trade is the ratio of $i$ 's GDP deflator to a geometric weighted average (based on GDP weights) of the GDP deflators of the remaining G7 countries, expressed in country $i$ currency using nominal exchange rates; the resulting series is logged and linearly detrended. For each country, we regressed that country's relative wage income $\widehat{w_{t} l_{t}}$ and dividend $\widehat{d_{t}}$ on $\widehat{q_{t}}$; the correlation between the residuals of those regressions is our estimate of $\operatorname{Corr}_{\widehat{q}}\left(\widehat{w_{t} l_{t}}, \widehat{d}_{t}\right)$, for that country. As shown in Table 1, $\operatorname{Corr}_{\widehat{q}}\left(\widehat{w_{t} l_{t}}, \widehat{d}_{t}\right)<0$, for all G7 countries.

\section{Implied equity portfolios}

Across G7 countries, the average capital share is $\kappa=0.4$; the average ratio of gross physical investment spending to GDP is $\Lambda=0.22$. The mean values (1984-2004) of the G7 countries's shares in total G7 GDP are: 0.44 (US), 0.19(Japan), 0.11 (Germany), 0.08(France), 0.06 (UK), 0.06 (Italy) and 0.04 (Canada), respectively. Using these values for $\kappa, \Lambda$ and $\mu_{i}$, and the estimates of $\operatorname{Cov}_{\widehat{q}}\left(\widehat{w_{t} l_{t}}, \widehat{d}_{t}\right) / \operatorname{Var}_{\widehat{q}}\left(\widehat{d}_{t}\right)$ shown in Table 1, we compute locally held equity shares $S_{i}^{i}$ predicted by the model (using (37)). The results are likewise shown in Table 1. The predicted degree of equity home bias $S_{i}^{i}-\mu_{i}$ is sizable and highly statistically significant: it ranges between $14 \%$ (US, Canada) and $84 \%$ (Japan). The implied locally held equity share $S_{i}^{i}$ ranges between $18 \%$ (Canada) and 103\% (Japan).

\section{The dynamics of external financial positions}

This Section describes the dynamics of the external financial positions of G7 countries; we then show that our model captures key aspects of the observed dynamics.

\subsection{External position dynamics: empirical evidence}

Table 2 reports standard deviations and (auto)correlations of annual financial/macroeconomic variables for the G7 countries, during the period 1984-2004. All statistics pertain to series that were detrended using the Hodrick-Prescott filter (smoothing parameter: 400). GDP, physical investment and real exchange rate series (CPI-based) were logged, before applying the filter.

The Table reports properties of the first difference (annual change) of countries' Net Foreign Assets (NFA) at market prices; see rows labelled " $\triangle \mathrm{NFA"} \mathrm{(NFA} \mathrm{changes} \mathrm{are} \mathrm{normalized} \mathrm{by} \mathrm{domestic} \mathrm{nominal}$ 
GDP). ${ }^{27}$ For 6 of the G7 countries, $\triangle \mathrm{NFA}$ is more volatile than GDP; the mean standard deviations of $\triangle$ NFA and GDP across the G7 countries are $3.23 \%$ and $2.07 \%$, respectively (see last Column of Table 2). NFA changes are countercyclical and essentially serially uncorrelated (mean correlation with domestic GDP: -0.22; mean autocorrelation: -0.01 )

As our model assumes trade in stocks and in bonds, we decompose the change of each country's NFA into the change of its net foreign equity assets and into the change of its net foreign bond assets, at market prices (normalized by domestic GDP) ${ }^{28}$ Equities and bonds both contribute noticeably to NFA changes: the average standard deviations of (normalized) changes of net foreign equity assets and of net foreign bond assets are $2.97 \%$ and $2.20 \%$, respectively. Changes in net foreign equity assets and net foreign bond assets are negatively correlated (mean correlation: -0.27). Like NFA changes, the changes of net foreign equity and net foreign bond positions have weak serial correlation; the changes of net foreign bond assets are countercyclical, while the changes of net foreign equity assets have no clear cyclical pattern.

The changes in the net foreign equity/bond assets at market prices reflect asset price (and exchange rate) changes, as well as net foreign asset acquisitions. The net foreign asset acquisition by a country, in a given period, is measured by its current account $(\mathrm{CA})$. In contrast to the first difference of NFA (at market prices), the CA does not take into account external capital gains/losses (on assets acquired in the past). Table 2 reports time series properties of the CAs of the G7 countries; we also disaggregate the CAs into 'Net equity purchases' from the rest of the world and 'Net bond purchases'. ${ }^{29}$ (CA and net equity/bond purchases series are normalized by domestic GDP). The CAs are only about a third as volatile as the NFA change (the mean standard deviation of CA $[\Delta \mathrm{NFA}]$ is $1.11 \%[3.23 \%]$ ). ${ }^{30}$ Thus, NFA changes are largely driven by valuation changes. Net equity purchases (mean standard deviation: $1.38 \%$ ) and net bond purchases (mean standard deviation: $1.71 \%$ ) are only sightly more volatile than the CA. Net equity/bond purchases are less volatile than changes in net foreign equity/bond positions

\footnotetext{
${ }^{27}$ The NFA data are from from Lane and Milesi-Ferretti (2006). Unless stated otherwise, the other data in this Section are from OECD National Accounts (macroeconomic aggregates, price indices) and International Financial Statistics (exchange rates).

${ }^{28}$ We measure a country's net equity as the sum of its net portfolio equity and net FDI positions; the net bond position is the sum of net debt and net bank loans (data from Lane and Milesi-Ferretti (2006)).

${ }^{29}$ Data source: IMF Balance of Payments Statistics. Our Net equity purchases variable is constructed as outflows minus inflows of 'Portfolio investment equity securities' + 'Direct investment'. Our Net debt purchases series represents outflowsinflows of 'portfolio investment debt securities' inflows + 'Other investment'.

${ }^{30}$ Kollmann (2006b) previously documented that CAs are less volatile than NFA changes, for a sample of.18 OECD countries. Faruquee and Lee (2007) confirm this empirical result for a sample of 100 countries.
} 
at market prices; the difference is especially noticeable for equities-which suggests that, valuation effects are more important for stocks than for bonds. Interestingly, net equity purchases are highly negatively (statistically significantly) correlated with net debt purchases (mean correlation: -0.68).

Finally, we note that net exports (normalized by GDP) are less volatile than GDP, while physical investment and the real exchange rate (CPI-based) are more volatile than GDP (mean standard deviations

of GDP, NX and RER: $2.07 \%, 1.14 \%$ and $8.38 \%$, respectively). Net exports are negatively correlated with domestic GDP (in 6 of the G7 countries), while the real exchange rate has no clear cyclical pattern (mean correlation with GDP: 0.12).

\subsection{External position dynamics: model predictions}

We now study the predictions of the model for the dynamics of foreign asset positions, capital flows and of key macroeconomic variables. We compare these predictions to the stylized facts described in the previous section.

\subsubsection{Model calibration}

We adopt a model calibration that closely follows the International Real Business Cycle literature (e.g. Backus, Kehoe and Kydland (1994), Kollmann (1996, 1998)). Like Backus et al., we set the degrees of consumption and investment home bias at $a=a_{I}=0.85$, which implies that the trade share (imports/GDP ratio) is $15 \%$ in the (deterministic) steady state.

The risk aversion coefficient, the labor supply elasticity, the substitution elasticity between domestic and foreign goods and the labor share (ratio of wage earnings to GDP) are set at $\sigma=2,1 / \omega=2, \phi=$ $\phi_{I}=2$ and $1-\kappa=0.6$, respectively; these parameter values are well in the range of empirical parameter estimates, for G7 countries (see Coeurdacier, Kollmann and Martin (2007) for a detailed justification).

The model is calibrated to annual data. As is standard in annual macro models, we set the subjective discount factor and the depreciation rate of capital at $\beta=0.96$ and $\delta=0.1$, respectively. This implies that, in steady state, the return on equity is about $4.16 \%$ p.a., the capital-output ratio is 2.82 , and $28 \%$ of GDP is used for investment. 
We assume that the exogenous variables follow $\mathrm{AR}(1)$ processes:

$$
\begin{aligned}
& \log \left(\theta_{i, t}\right)=\rho^{\theta} \log \left(\theta_{i, t-1}\right)+\varepsilon_{i, t}^{\theta}, \\
& \log \left(\chi_{i, t}\right)=\rho^{\chi} \log \left(\chi_{i, t-1}\right)+\varepsilon_{i, t}^{\chi} \quad \text { for } i=H, F .
\end{aligned}
$$

We fitted (38) to detrended annual (log) TFP series, for each G7 country (1972-2004). ${ }^{31}$ The estimates of $\rho^{\theta}$ range between 0.64 (US) and 0.80 (Canada); the mean autocorrelation (across G7 countries) is 0.75 . The standard deviation of $\varepsilon_{i, t}^{\theta}$ ranges between $1.01 \%$ (France) and $1.48 \%$ (Japan), with a mean of $1.20 \%$. TFP is positively correlated across countries; for each G7 country, we constructed a measure of 'foreign' TFP, by taking a weighted average (using GDP weights) of (log) TFP in the remaining G7 countries; we then fitted (38) to (linearly detrended) 'foreign' (log) TFP. The correlation of domestic-foreign productivity innovation ranges between 0.29 (UK) and 0.70 (Germany), with an average correlation of 0.45 . We thus set $\rho^{\theta}=0.75, \operatorname{Std}\left(\varepsilon_{H, t}^{\theta}\right)=\operatorname{Std}\left(\varepsilon_{F, t}^{\theta}\right)=1.20 \%, \operatorname{Corr}\left(\varepsilon_{H, t}^{\theta}, \varepsilon_{F, t}^{\theta}\right)=0.45 . \quad 32$

When $a=a_{I}$ holds, one unit of the country $i$ aggregate investment good in efficiency units is worth $1 / \chi_{i, t}$ units of the aggregate consumption good in that country. The literature on investment specific technology shocks has used the ratio of the CPI to the price deflator of investment spending as an estimate of investment specific technology shocks (see Fisher (2006)). We follow that literature. For each G7 country, we computed annual time series of $\chi_{i, t} \equiv \mathrm{CPI} /$ (investment deflator), for the period 1972-2004 (data source: OECD National Accounts). ${ }^{33}$ The autocorrelations of (linearly detrended) $\log \left(\chi_{i, t}\right)$ range between 0.93 (US) and 0.79 (Canada); the mean autocorrelation is 0.79 . The standard deviations of $\varepsilon_{i, t}^{\chi}$ ranges between $1.18 \%$ (US) and $2.48 \%$ (Japan), with a mean of $1.73 \%$. Innovations to investment efficiency in country $i$ and in a rest-of-G7 aggregate are only weakly correlated (mean correlation: 0.19). Empirically, $\log \left(\chi_{i, t}\right)$ is thus roughly as persistent as $\log \left(\theta_{i, t}\right)$, but more volatile, and less correlated across countries. Based on this evidence, we set $\rho^{\chi}=0.79, \operatorname{Std}\left(\varepsilon_{H, t}^{\chi}\right)=\operatorname{Std}\left(\varepsilon_{F, t}^{\chi}\right)=1.73 \%$,

\footnotetext{
${ }^{31}$ Our estimate of country i TFP (in $\left.\operatorname{logs}\right)$ is: $\log \left(T F P_{i, t}\right)=\log \left(y_{i, t}\right)-\left(1-\kappa_{i}\right) \log \left(l_{i, t}\right)$, with $1-\kappa_{i}$ : i's mean labor share during the sample period; $L_{i, t}$ : total hours worked (from OECD Productivity Database). No capital stocks were used, due to the absence of consistent capital data in G7 countries, during sample period.

${ }^{32}$ We also estimated VARs in home and foreign TFP: $\left(\log \left(\theta_{H, t}\right), \log \left(\theta_{F, t}\right)\right)=R\left(\log \left(\theta_{H, t-1}\right), \log \left(\theta_{F, t-1}\right)\right)+\epsilon_{t}^{\theta}$ where $R$ is a $2 \times 2$ matrix. We find that the off-diagonal elements of $R$ are generally not statistically significant; the mean value (across G7 countries) of the off-diagonal elements is zero. The simulations thus assume univariate technology processes with innovations that are correlated across countries.

${ }^{33}$ The empirical literature on investment specific technology shocks has focused on the US. It documents a secular fall in the real price of investment goods (relative to the CPI). Our data show that a similar downward trend exists in the remaining G7 countries. In 1972-2004, the average annual rates of decline of the relative price of investment were: $0.99 \%$ (US), $0.84 \%$ (Japan), $0.52 \%$ (Germany) $0.35 \%$ (France), 0.66\% (UK), 0.32\% (Italy), $1.33 \%$ (Canada).
} 
$\operatorname{Corr}\left(\varepsilon_{H, t}^{\chi}, \varepsilon_{F, t}^{\chi}\right)=0.19$.

The correlations between TFP and investment efficiency innovations $\left(\varepsilon_{i, t}^{\theta}, \varepsilon_{i, t}^{\chi}\right)$ are close to zero (mean correlation: 0.0003$)$. In the calibration, we thus assume that TFP and investment efficiency shocks are independent.

\subsubsection{Numerical solution method}

We numerically solve for first-order accurate prices, quantities and (time-varying) equilibrium portfolios, building on Devereux and Sutherland (2006b). ${ }^{34}$ The numerical solution expresses portfolios held at the end of period $t$ as a linear function of endogenous predetermined variables set at $t$, and of exogenous variables realized at $t: S_{j, t+1}^{i}=S_{j}^{i}+\gamma_{j}^{S, i}\left(Z_{t}-Z\right), b_{j, t+1}^{i}=b_{j}^{i}+\gamma_{j}^{b, i}\left(Z_{t}-Z\right)$ for $i, j=H, F$, with $Z_{t} \equiv\left(K_{H, t+1}, K_{F, t+1}, N F A_{H, t+1}, \theta_{H, t}, \theta_{F, t}, \chi_{H, t}, \chi_{F, t}\right)$, where $N F A_{H, t}$ is the Home country net foreign asset position at the end of period $t$ (see below). The coefficients $\gamma_{j}^{S, i}, \gamma_{j}^{b, i}$ of these linear portfolio decision rules can be computed using a third-order accurate approximation of the household Euler equations, and a second-order accurate approximation of the remaining equilibrium conditions. We use the Sims (2000) algorithm for that purpose.

\subsubsection{Numerical results}

Table 3 shows predicted moments of (first-order accurate) Home country variables. Net foreign assets, net foreign equity/bond assets, the current account, net equity/bond purchases and net exports are normalized by Home GDP. Statistics for (real) GDP and physical investment pertain to logged series. All statistics are based on Hodrick-Prescott filtered variables (smoothing parameter: 400). ${ }^{35}$ That normalization/filter parallels the normalization/filter applied to the empirical series in Table 2.

The theoretical counterparts to the empirical financial variables considered in Table 2 are defined as follows: The Home country's net foreign equity assets (at market prices) at the end of period t are $p_{F, t}^{S} S_{F, t+1}^{H}-p_{H, t}^{S} S_{H, t+1}^{F}$, while Home net foreign bond assets (at market prices) are: $p_{H, t}^{b} b_{H, t+1}^{H}+p_{F, t}^{b} b_{F, t+1}^{H}$. Net Foreign Assets are the sum of net foreign equity assets and net foreign bond assets. The Home net

\footnotetext{
${ }^{34}$ Devereux and Sutherland (2006b) compute dynamic portfolios in an economy with two assets; we extend their method to the case with more than two assets.

${ }^{35}$ Predicted moments are computed by applying the Hodrick-Prescott filter to the moving average representation of the linearized model solution (using formulae for Hodrick-Prescott filter weights derived by McElroy (2008)).
} 
equity purchase in period t is $p_{F, t}^{S} \Delta S_{F, t+1}^{H}-p_{H, t}^{S} \Delta S_{H, t+1}^{F}$ (with $\left.\Delta x_{t+1} \equiv x_{t+1}-x_{t}\right)$; the Home net bonds purchase is $p_{H, t}^{b} \Delta b_{H, t+1}^{H}+p_{F, t}^{b} \Delta b_{F, t+1}^{H}$. The current account is the sum of net bond and equity purchases. Up to the linear approximation used here, the change in a country's NFA equals the current account plus the change in market value of steady state external stock and bond holdings: $\triangle N F A_{H, t+1}=$ $C A_{H, t}+\left(\Delta p_{F, t}^{S}-\Delta p_{H, t}^{S}\right)(1-S)+\left(\Delta p_{H, t}^{b}-\Delta p_{F, t}^{b}\right) b .{ }^{36}$ Similarly, the change in net foreign equity [bond] assets (at market prices) equals net equity [bond] purchases, plus the change in the market value of the steady state stock [bond] holdings. In Table 3 (as in the model) we define the real exchange rate as the relative price of Home aggregate consumption in terms of Foreign aggregate consumption; see (21) (thus, a fall in $R E R_{t}$ represents a depreciation of the Home real exchange rate).

\section{Zero-order portfolio}

The zero-order equilibrium portfolio is: $S=0.79, \widetilde{b}=0.26$. Thus, $79 \%$ of a country's capital stock is predicted to be held by local investors.

\section{Predicted dynamic properties}

Col. 1 of Table 3 reports predicted statistics for the model, with the two types of shocks. In order to assess the relative importance of each type of shock, we also report predicted statistics for variants with only TFP shocks (Col. 2) and with only investment efficiency shocks (Col. 3). ${ }^{37}$ Col. 4 reports average historical statistics for the G7 countries.

Table 3 shows that the model generates sizable fluctuations in equity and bond holdings: the predicted standard deviations of a country's net bond purchases and of its net equity purchases are both $3.23 \%$ (the mean empirical standard deviations of net bond and net equity purchases are $1.71 \%$ and $1.38 \%$, respectively); the $\theta$ and $\chi$ shocks both account for roughly the same share of the variance of net equity/bond purchases. However, up to a first order approximation, these net asset purchases do not affect the current account: in each period, the value of net equity purchases equals the value of net bond sales (see proof in Appendix). The model thus predicts that net bond purchases are perfectly negatively correlated with net equity purchases. Empirically, net bond purchases and net equity purchases are strongly negatively

\footnotetext{
${ }^{36}$ To see this, note that, up to first order, the country $\mathrm{H}$ current account, and the first difference of H's net foreign assets are $C A_{H, t}=p^{S}\left(\Delta S_{F, t+1}^{H}-\Delta S_{H, t+1}^{F}\right)+p^{b}\left(\Delta b_{H, t+1}^{H}+\Delta b_{F, t+1}^{H}\right), \Delta N F A_{H, t+1}=p^{S}\left(\Delta S_{F, t+1}^{H}-\Delta S_{H, t+1}^{F}\right)+p^{b}\left(\Delta b_{F, t+1}^{H}+\right.$ $\left.\Delta b_{H, t+1}^{F}\right)+\left(\Delta p_{F, t}^{S}-\Delta p_{H, t}^{S}\right)(1-S)+\left(\Delta p_{H, t}^{b}-\Delta p_{F, t}^{b}\right) b$.

${ }^{37}$ Cols. 2 and 3 assume the equilibrium decision rules and price functions of the model with both types of shocks - we merely feed just one type of disturbances into the model.
} 
correlated (mean correlation: -0.68).

The model captures the fact that the persistence of net equity/bond purchases is much lower than the persistence of GDP: the predicted autocorrelations of net equity and net bond purchases are close to zero (0.07). This is due to the fact that equity and bond holdings at the end of period $t\left(S_{i, t+1}^{j}, b_{i, t+1}^{j}\right)$ are functions of state variables (capital stocks, Net Foreign Assets and exogenous variables) that are highly persistent; thus, the first difference of net equity/bond holdings (i.e. net equity/bond purchases) has little serial correlation.

The predicted standard deviation, correlation with GDP and autocorrelation of the first difference of Net Foreign Assets (with simultaneous two types of shocks) are 2.21\%, -0.26 and 0.12 , respectively (corresponding average empirical statistics: $3.23 \%,-0.22,-0.01$ ). Consistent with the data, the model predicts thus that the change of NFA is more volatile than GDP, countercyclical and basically serially uncorrelated. As the current account is predicted to be zero (up to first order), NFA changes are solely driven by movements in asset prices. NFA is thus predicted to have the time series properties of asset prices. When there is a positive TFP or investment efficiency shock, net imports are predicted to rise on impact (due to a strong short run rise in investment), and to fall thereafter; the present value of future net imports drops, on impact. As the country's NFA equals the present value of its current and future net imports, the NFA drops too on impact. This explains why the change in NFA is predicted to be countercyclical.

With just TFP shocks [just investment efficiency shocks] the predicted standard deviation of the change in NFA is $1.72 \%$ [1.39\%] (see Cols., 2 and 3, Table 3). Thus, investment efficiency shocks contribute noticeably to the model's ability to generate volatile NFA changes.

The changes of net foreign equity assets and of net foreign bond assets too are predicted to exhibit sizable fluctuation (predicted standard deviations with the two simultaneous types of shocks: $5.32 \%$ and $3.13 \%$, respectively). As in the data, the changes of net equity assets and of net bond assets are negatively correlated.

The model (with simultaneous $\theta$ and $\chi$ shocks) matches closely the observed volatility of GDP, and it captures the fact that investment spending is markedly more volatile than GDP (predicted standard deviations of GDP and investment: $1.87 \%, 8.26 \%$ ). The predicted standard deviation of net exports 
$(1.07 \%)$ is close to the empirical standard deviation (1.14\%). The model predicts that net exports are weakly countercyclical. Cols. 2 and 3 show that TFP shocks are the main source of output fluctuations, but that investment and net exports are mainly driven by investment efficiency shocks $(\chi) . \quad \chi$ also generates countercyclical fluctuations of net exports. The model captures the fact that the fluctuations of GDP, investment and net exports are persistent.

The high volatility of the real exchange rate is one of the key puzzles of international macroeconomics. Standard RBC models (driven just by TFP shocks) underpredict sharply the observed volatility of real exchange rates; those models also predicts that the real external value of a currency (and the terms of trade) is highly countercyclical (see, e.g., Backus et al. (1994)). The model here, with the two types of shocks, performs somewhat better. With just TFP shocks, the predicted standard deviation of the real exchange rate and its correlation with domestic GDP are $0.60 \%$ and -0.52 , respectively. Adding the investment efficiency shock more than doubles the predicted standard deviation of the real exchange rate (to $1.38 \%$ ), and raises the predicted correlation with GDP to -0.22 (the empirical correlation is 0.08). When there are just $\chi$ shocks, the real exchange rate is essentially acyclical. On impact, a positive Home investment efficiency shock appreciates the Home country's terms of trade and its real exchange rate (the increase in Home investment triggered by the shock raises relative demand for the $\mathrm{H}$ good, as there is local bias in investment spending); however, in subsequent periods, the real exchange rate depreciates (once Home has increased its capital stock, the supply of the $\mathrm{H}$ good is above its pre-shock level, and thus its relative prices is lower). This explains why, with the simultaneous two types of shock, the real exchange rate is much less cyclical than with just TFP shocks.

\section{Conclusion}

This paper departs from the two familiar explanations of equity home bias: transaction costs that impede international diversification, and the possibility that terms of trade responses to supply shocks provide international risk sharing, so that households have little incentive to hold diversified portfolios (Cole and Obstfeld (1991), Helpman and Razin (1978)). We study a two-country/two-good RBC model with

frictionless international trade in stocks and in bonds; there are shocks to total factor productivity and to the efficiency of physical investment. In the setting here, domestic stocks are used to hedge fluctuations 
in local wage income triggered by shocks to investment spending. Terms of trade risk is hedged using bonds denominated in local goods and in foreign goods. In contrast to related models, the low level of international diversification does not depend on strongly countercyclical terms of trade. Investment efficiency shocks allow the model to generate more realistic volatility in net foreign assets and net exports. 


\section{APPENDIX}

\section{A.1. Verifying that the period-by-period household budget constraint (12) is satisfied and that the current account is zero, to first order}

In deriving the zero-order equilibrium portfolio $(S, b)$, we replaced the period-by-period household budget constraint (12) by the 'static' constraint (26). We now show that when a first-order approximation of the 'static' constraint holds at all dates, then a first-order approximation of (12) holds likewise. Thus it is sufficient to consider the 'static' constraint (26) when solving for $(S, b)$.

Following Devereux and Sutherland (2006a,b), we express the period $t$ budget constraint (12) of country $i$ as

$$
\begin{aligned}
N F A_{i, t+1} & =N X_{i, t}+N F A_{i, t} R_{t}^{b, i}+\xi_{i, t}, \quad \text { with } \\
N F A_{i, t+1} & \equiv p_{j, t}^{S} S_{j, t+1}^{i}-p_{i, t}^{S} S_{i, t+1}^{j}+p_{i, t}^{b} b_{i, t+1}^{i}+p_{j, t}^{b} b_{j, t+1}^{i}, \quad j \neq i, \\
N X_{i, t} & \equiv p_{i, t} y_{i, t}-P_{i, t} C_{i, t}-P_{i, t}^{I} I_{i, t}, \\
\xi_{i, t} & \equiv S_{j, t}^{i} p_{j, t-1}^{S}\left(R_{j, t}^{S}-R_{i, t}^{b}\right)-S_{i, t}^{j} p_{i, t-1}^{S}\left(R_{i, t}^{S}-R_{i, t}^{b}\right)+b_{j, t}^{i} p_{j, t-1}^{b}\left(R_{j, t}^{b}-R_{i, t}^{b}\right), \quad j \neq i .
\end{aligned}
$$

$N F A_{i, t+1}$ are country $i$ 's net foreign assets at the end of period $t$, and $N X_{i, t}$ are $i$ 's net exports. $R_{i, t}^{S}, R_{j, t}^{S}, R_{i, t}^{b}, R_{j, t}^{b} \quad$ are gross equity/bond returns between $t-1$ and $t$ (see (15)). $\xi_{i, t}$ is the "excess return" on the country's net foreign assets (between $t-1$ and $t$ ) relative to the return on the good- $i$ bond..$^{38}$

As before, variables without time indices represent (deterministic) steady state values, and $\widehat{z_{i, t}} \equiv$ $\left(z_{i, t}-z_{i}\right) / z_{i}$. Note that $N F A_{i}=0, N X_{i}=0, p^{S} \equiv p_{H}^{S}=p_{F}^{S}, \quad p^{b} \equiv p_{H}^{b}=p_{F}^{b}, d \equiv d_{H}=d_{F}$, $p \equiv p_{H}=p_{F}$, due to the symmetric structure of the two countries; also, $R_{H}^{S}=R_{F}^{S}=R_{H}^{b}=R_{F}^{b}=1 / \beta$. A linear approximation of (40) around the steady state yields thus:

$$
N F A_{i, t+1}=N X_{i, t}+N F A_{i, t} / \beta+S_{j}^{i} p^{S} \frac{1}{\beta}\left(\widehat{R_{j, t}^{S}}-\widehat{R_{i, t}^{b}}\right)-S_{i}^{j} p^{S} \frac{1}{\beta}\left(\widehat{R_{i, t}^{S}}-\widehat{R_{i, t}^{b}}\right)+b_{j}^{i} p^{b} \frac{1}{\beta}\left(\widehat{R_{j, t}^{b}}-\widehat{R_{i, t}^{b}}\right), \quad j \neq i
$$

\footnotetext{
${ }^{38}$ Note that $\xi_{i, t}=S_{j, t}^{i}\left(d_{j, t}+p_{i, t}^{S}\right)-S_{i, t}^{j}\left(d_{i, t}+p_{i, t}^{S}\right)+\left(p_{i, t}+p_{i, t}^{b}\right) b_{i, t}^{i}+\left(p_{j, t}+p_{j, t}^{b}\right) b_{j, t}^{i}-N F A_{i, t} R_{i, t}^{b}$. Thus, $\xi_{i, t}$ is the difference between country $i^{\prime} s$ net external wealth (including net dividend and coupon income) at the beginning of period $t$, minus the hypothetical value of $i^{\prime} s$ net external wealth at the beginning of $t$ that would obtain if $i$ fully invested her net external wealth at the end of $t-1$ in the good- $i$ bond.
} 
where $S_{j}^{i}, S_{i}^{j}, b_{i}^{i}$ and $b_{j}^{i}$ are zero-order portfolio holdings. Symmetry implies $S_{i}^{j}=S_{j}^{i}=1-S ; b=b_{i}^{i}=-b_{j}^{i}$, for $j \neq i$. Hence:

$$
N F A_{i, t+1}=N X_{i, t}+N F A_{i, t} / \beta+(S-1) p^{S} \frac{1}{\beta}\left(\widehat{R_{i, t}^{S}}-\widehat{R_{j, t}^{S}}\right)+b p^{b} \frac{1}{\beta}\left(\widehat{R_{i, t}^{b}}-\widehat{R_{j, t}^{b}}\right), \quad j \neq i .
$$

Solving the Euler equations (14) forward gives $p_{i, t}^{S}=E_{t} \sum_{\tau \geq 1} \varrho_{t, t+\tau}^{i} d_{i, t+\tau}$ and $p_{i, t}^{b}=E_{t} \sum_{\tau \geq 1} \varrho_{t, t+\tau}^{i} p_{i, t+\tau}$.Up to first order, the relative stock and bond prices and returns obey thus:

$$
\begin{aligned}
& \widehat{p_{i, t}^{S}}-\widehat{p_{j, t}^{S}}=\frac{1-\beta}{\beta} E_{t} \sum_{\tau \geq 1} \beta^{\tau}\left(\widehat{d_{i, t+\tau}}-\widehat{d_{j, t+\tau}}\right), \widehat{p_{i, t}^{b}}-\widehat{p_{j, t}^{b}}=\frac{1-\beta}{\beta} E_{t} \sum_{\tau \geq 1} \beta^{\tau}\left(\widehat{p_{i, t+\tau}}-\widehat{p_{j, t+\tau}}\right), j \neq i, \\
& \widehat{R_{i, t}^{S}}-\widehat{R_{j, t}^{S}}=(1-\beta) \widetilde{E_{t}} \sum_{\tau \geq 0} \beta^{\tau}\left(\widehat{d_{i, t+\tau}}-\widehat{d_{j, t+\tau}}\right), \widehat{R_{i, t}^{b}}-\widehat{R_{j, t}^{b}}=(1-\beta) \widetilde{E_{t}} \sum_{\tau \geq 0} \beta^{\tau}\left(\widehat{p_{i, t+\tau}}-\widehat{p_{j, t+\tau}}\right), \quad j \neq i .
\end{aligned}
$$

with $\widetilde{E_{t}} z \equiv E_{t} z-E_{t-1} z$ (revision of expectation between $t-1$ and $\left.t\right)$. Thus, $E_{t}\left(\widehat{R_{i, t+\tau}^{S}}-\widehat{R_{j, t+\tau}^{S}}\right)=$ $E_{t}\left(\widehat{R_{i, t+\tau}^{b}}-\widehat{R_{j, t+\tau}^{b}}\right)=0$ for $\tau>0$ : up to first order, the expected value of future excess returns is zero.

Solving (42) forward (imposing the no-Ponzi/transversality condition $\lim _{\tau \rightarrow \infty} E_{t} \beta^{\tau} N F A_{i, t+\tau}=0$ ) gives the following present value budget constraint:

$E_{t} \sum_{\tau \geq 0} \beta^{\tau}\left(-N X_{i, t+\tau}\right)=N F A_{i, t} / \beta+(S-1) d \widetilde{E_{t}} \sum_{\tau \geq 0} \beta^{\tau}\left(\widehat{d_{i, t+\tau}}-\widehat{d_{j, t+\tau}}\right)+b p \widetilde{E_{t}} \sum_{\tau \geq 0} \beta^{\tau}\left(\widehat{p_{i, t+\tau}}-\widehat{p_{j, t+\tau}}\right), j \neq i$,

where we used that fact that $p^{S}=d \beta /(1-\beta), p^{b}=p \beta /(1-\beta)$.

(45) holds if and only if:

$$
\begin{gathered}
\widetilde{E_{t}} \sum_{\tau \geq 0} \beta^{\tau}\left(-N X_{i, t+\tau}\right)=(S-1) d \widetilde{E_{t}} \sum_{\tau \geq 0} \beta^{\tau}\left(\widehat{d_{i, t+\tau}}-\widehat{d_{j, t+\tau}}\right)+b p \widetilde{E_{t}} \sum_{\tau \geq 0} \beta^{\tau}\left(\widehat{p_{i, t+\tau}}-\widehat{p_{j, t+\tau}}\right), \quad j \neq i \\
\text { and } E_{t-1} \sum_{\tau \geq 0} \beta^{\tau}\left(-N X_{i, t+\tau}\right)=N F A_{i, t} / \beta .
\end{gathered}
$$

(46) shows that, up to first order, date $t$ innovations to the expected present value of current and future country $i$ net imports have to equal innovations to the present value of net dividend and net bond income received by country $i$.

\section{The 'static' budget constraint}

In deriving the zero-order equilibrium portfolio, we replaced the period-by-period household budget constraint (12) by the 'static' budget constraint: $P_{i, t} C_{i, t}=w_{i, t} l_{i, t}+S d_{i, t}+(1-S) d_{j, t}+b\left(p_{i, t}-p_{j, t}\right) \quad($ see 
(26)). This constraint can be expressed as: $-N X_{i, t}=(S-1)\left(d_{i, t}-d_{j, t}\right)+b\left(p_{i, t}-p_{j, t}\right) \cdot{ }^{39}$ Equivalently:

$$
-N X_{i, t}=(S-1) d\left(\widehat{d_{i, t}}-\widehat{d_{j, t}}\right)+b p\left(\widehat{p_{i, t}}-\widehat{p_{j, t}}\right), \quad j \neq i .
$$

It is clear that when (48) holds at all dates, then the present value budget constraint (46) is also satisfied. We show next that (47) entails a restriction on the first-order (time-varying) deviations of portfolio holdings from zero-order portfolio holdings. This implies that, when solving for the zero-order portfolio zero-order portfolio $(S, b)$, it is sufficient to consider the 'static' budget constraint (26).

\section{A restriction on first-order accurate (time-varying) portfolio holdings}

Substitution of (48) into (47) yields:

$$
N F A_{i, t}=(S-1) \beta E_{t-1} \sum_{\tau \geq 0} \beta^{\tau} d\left(\widehat{d_{i, t+\tau}}-\widehat{d_{j, t+\tau}}\right)+b \beta E_{t-1} \sum_{\tau \geq 0} \beta^{\tau} p\left(\widehat{p_{i, t+\tau}}-\widehat{p_{j, t+\tau}}\right), \quad j \neq i .
$$

Using the formulae for relative asset prices (43), we can write this as:

$$
N F A_{i, t}=(S-1) p^{S}\left(\widehat{p_{i, t-1}^{S}}-\widehat{p_{j, t-1}^{S}}\right)+b p^{b}\left(\widehat{p_{i, t-1}^{b}}-\widehat{p_{j, t-1}^{b}}\right), \quad j \neq i .
$$

Linearizing the expression $N F A_{i, t}=p_{j, t-1}^{S} S_{j, t}^{i}-p_{i, t-1}^{S} S_{i, t}^{j}+p_{i, t-1}^{b} b_{i, t}^{i}+p_{j, t-1}^{b} b_{j, t}^{i}$ gives

$$
\left.N F A_{i, t} \equiv(S-1) p^{S} \widehat{\left(p_{i, t-1}^{S}\right.}-\widehat{p_{j, t-1}^{S}}\right)+b p^{b} \widehat{\left(p_{i, t-1}^{b}-\widehat{p_{j, t-1}^{b}}\right)}+\left(\nabla S_{j, t}^{i}-\nabla S_{i, t}^{j}\right) p^{S}+\left(\nabla b_{i, t}^{i}+\nabla b_{j, t}^{i}\right) p^{b}, j \neq i,
$$

where $\nabla S_{j, t}^{i} \equiv S_{j, t}^{i}-(1-S), \nabla S_{i, t}^{j} \equiv S_{i, t}^{j}-(1-S), \nabla b_{i, t}^{i} \equiv b_{i, t}^{i}-b, \nabla b_{j, t}^{i} \equiv b_{j, t}^{i}-(-b)$ denote the deviations of portfolio holdings at the end of period $t-1$ from the zero-order portfolio. (50) and (51) imply that, to first order, the value of country' net external assets, evaluated at steady state asset prices is zero:

$$
\left(\nabla S_{j, t}^{i}-\nabla S_{i, t}^{j}\right) p^{S}+\left(\nabla b_{i, t}^{i}+\nabla b_{j, t}^{i}\right) p^{b}=\left(S_{j, t}^{i}-S_{i, t}^{j}\right) p^{S}+\left(b_{i, t}^{i}+b_{j, t}^{i}\right) p^{b}=0, \quad j \neq i .
$$

\section{The current account}

(52) implies that the current account is zero, to first order. The period $t$ current account of country $i$ is: $C A_{i, t}=\left(S_{j, t+1}^{i}-S_{j, t}^{i}\right) p_{j, t}^{S}-\left(S_{i, t+1}^{j}-S_{i, t}^{j}\right) p_{i, t}^{S}+\left(b_{i, t+1}^{i}-b_{i, t}^{i}\right) p_{i, t}^{b}+\left(b_{j, t+1}^{i}-b_{j, t}^{i}\right) p_{i, t}^{b}$. Linearization of this expression gives: $C A_{i, t}=\left\{\left(S_{j, t+1}^{i}-S_{j, t}^{i}\right)-\left(S_{i, t+1}^{j}-S_{i, t}^{j}\right)\right\} p^{S}+\left(b_{i, t+1}^{i}-b_{i, t}^{i}+b_{j, t+1}^{i}-b_{j, t}^{i}\right) p^{b}$. If thus follows from (52) that $C A_{i, t}=0$, up to first order.

\footnotetext{
${ }^{39}$ Subtracting $w_{i, t} l_{i, t}$ and $d_{i, t}$ from both sides of the static constraint gives: $P_{i, t} C_{i, t}-w_{i, t} l_{i, t}-d_{i, t}=(S-1)\left(d_{i, t}-\right.$ $\left.d_{j, t}\right)+b\left(p_{i, t}-p_{j, t}\right)$.The left-hand side of thsi expression equals $-N X_{i, t}\left(\right.$ as $\left.d_{i, t} \equiv p_{i, t} y_{i, t}-w_{i, t} l_{i, t}-P_{i, t}^{I} I_{i, t}\right)$.
} 


\section{A.2. Returns and the equilibrium portfolio}

Equation (36) in the main text shows that the zero-order local equity position $S$ depends on the covariance between components of relative (Home vs. Foreign) wage incomes and dividend payments that are orthogonal to the terms of trade: $S=\frac{1}{2}-\frac{1}{2} \frac{1-\kappa}{\kappa-\Lambda} \frac{\operatorname{Cov} \widehat{q}\left(\widehat{w_{t} l_{t}}, \widehat{d_{t}}\right)}{\operatorname{Var}\left(\widehat{d}_{t}\right)}$. We now show that $S$ can equivalently be expressed as a function of the covariance between between components of relative (Home vs. Foreign) human capital returns and equity returns that are orthogonal to the return differential between the Home-good and Foreign-good bonds.

As shown above, country $i$ net imports can be expressed as: $-N X_{i, t}=P_{i, t} C_{i, t}-w_{i, t} l_{i, t}-d_{i, t}$; this can be written as: $-N X_{i, t}=p y_{i}(1-\Lambda) \widehat{P_{i, t} C_{i, t}}-(1-\kappa) p y_{i} \widehat{w_{i, t} l_{i, t}}-p y_{i}(\kappa-\Lambda) \widehat{d_{i, t}} \cdot{ }^{40} \quad$ Inserting this expression into (46) gives:

$$
\begin{array}{r}
(1-\Lambda) \widetilde{E_{t}} \sum_{\tau \geq 0} \beta^{\tau} P_{i, t+\tau} \widehat{C}_{i, t+\tau}=(1-\kappa) \widetilde{E_{t}} \sum_{\tau \geq 0} \beta^{\tau} w_{i, t+\tau} \widehat{l_{i, t+\tau}}+S(\kappa-\Lambda) \widetilde{E_{t}} \sum_{\tau \geq 0} \beta^{\tau} \widehat{d_{i, t+\tau}} \\
+(1-S)(\kappa-\Lambda) \widetilde{E_{t}} \sum_{\tau \geq 0} \beta^{\tau} \widehat{d_{j, t+\tau}}+\widetilde{b} \widetilde{E}_{t} \sum_{\tau \geq 0} \beta^{\tau}\left(\widehat{p_{i, t+\tau}}-\widehat{p_{j, t+\tau}}\right), \quad j \neq i .
\end{array}
$$

where $\widetilde{b} \equiv b / y_{i}$ is the local-good bond holding divided by steady state output.

Subtracting the linearized present value budget constraint (53) of country F from that of country $\mathrm{H}$ yields:

$$
\begin{array}{r}
(1-\Lambda) \widetilde{E_{t}} \sum_{\tau \geq 0} \beta^{\tau}\left[P_{H, t+\tau} C_{H, t+\tau}-P_{F, t+\tau} C_{F, t+\tau}\right]=(1-\kappa) \widetilde{E_{t}} \sum_{\tau \geq 0} \beta^{\tau}\left[\widehat{\left[w_{H, t+\tau} l_{H, t+\tau}\right.}-\widehat{w_{H, t+\tau} l_{H, t+\tau}}\right]+ \\
(2 S-1)(\kappa-\Lambda) \widetilde{E_{t}} \sum_{\tau \geq 0} \beta^{\tau}\left[\widehat{d_{H, t+\tau}}-\widehat{d_{F, t+\tau}}\right]+2 \widetilde{b E_{t}} \sum_{\tau \geq 0} \beta^{\tau} \widehat{q_{t+\tau}},
\end{array}
$$

where $q_{t} \equiv p_{H, t} / p_{F, t}$ are the Home terms of trade. Effective market completeness (up to first order) implies that $\widehat{P_{H, t} C_{H, t}}-\widehat{P_{F, t} C_{F, t}}=\left(1-\frac{1}{\sigma}\right) q_{t}$ (see $(27)$ ). Thus, innovations to the present value of relative consumption spending are perfectly correlated with the return differential between Home-good and Foreign-good bonds (from (44)):

$$
\widetilde{E_{t}} \sum_{\tau \geq 0} \beta^{\tau}\left[P_{H, t+\tau} C_{H, t+\tau}-P_{F, t+\tau} C_{F, t+\tau}\right]=\left(1-\frac{1}{\sigma}\right) \frac{1}{1-\beta}\left(R_{H, t}^{b}-R_{F, t}^{b}\right) .
$$

\footnotetext{
${ }^{40}$ NB Steady state consumption spending is a fraction $(1-\Lambda)$ of output, where $\Lambda$ is the steady state ratio of investment spending t GDP; wage income and dividends account for fractions $1-\kappa$ and $\kappa-\Lambda$ of output, respectively.
} 
Define the return on country $i$ Human capital as: $R_{i, t}^{W} \equiv \frac{P_{i, t}^{W}+w_{i, t} l_{i, t}}{P_{i, t}^{W}}$, where $P_{i, t}^{W} \equiv E_{t} \sum_{\tau \geq 1} \varrho_{t, t+\tau}^{i} w_{i, t+\tau} l_{i, t+\tau}$ is the present value of the country $i$ labor income; linearizing these formulae gives:

$$
\widehat{R_{H, t}^{W}}-\widehat{R_{F, t}^{W}}=(1-\beta) \widetilde{E_{t}} \sum_{\tau \geq 0} \beta^{\tau}\left[w_{H, t+\tau} l_{H, t+\tau}-\widehat{w_{F, t+\tau} l_{F, t+\tau}}\right] .
$$

Using the expression for the cross-country equity return differential shown in (44), we can thus express (54) as:

$$
(1-\Lambda)\left(1-\frac{1}{\sigma}\right) R_{t}^{b}=(1-\kappa) R_{t}^{W}+(2 S-1)(\kappa-\Lambda) R_{t}^{S}+2 \widetilde{b} R_{t}^{b} .
$$

where $R_{t}^{b} \equiv R_{H, t}^{b}-R_{F, t}^{b}, \quad R_{t}^{W} \equiv R_{H, t}^{W}-R_{F, t}^{W}, \quad R_{t}^{S} \equiv R_{H, t}^{S}-R_{F, t}^{S}$ are Home-Foreign return differentials for bonds, Human capital and equity, respectively. This condition implies:

$$
S=\frac{1}{2}-\frac{1}{2} \frac{1-\kappa}{\kappa-\Lambda} \frac{\operatorname{Cov}_{R^{b}}\left(R_{t}^{W}, R_{t}^{S}\right)}{\operatorname{Var}_{R^{b}}\left(R_{t}^{S}\right)},
$$

with $\operatorname{Cov}_{R^{b}}\left(R_{t}^{W}, R_{t}^{S}\right) \equiv E\left\{R_{t}^{W}-P\left[R_{t}^{W} \mid R_{t}^{b}\right]\right\}\left\{R_{t}^{S}-P\left[R_{t}^{S} \mid R_{t}^{b}\right]\right\}, \operatorname{Var}_{R^{b}}\left(R_{t}^{S}\right) \equiv E\left\{R_{t}^{S}-P\left[R_{t}^{S} \mid R_{t}^{b}\right]\right\}^{2}$, where $P\left[R_{t}^{W} \mid R_{t}^{b}\right]$ is the linear projection of $R_{t}^{W}$ on $R_{t}^{b}$. Thus, the local equity share can be expressed as a function of the covariance between the components of relative (Home vs. Foreign) human capital returns and (relative) equity returns that are orthogonal to (relative) bond returns: equity home bias arises when that covariance is negative.

The model here generates a negative covariance. In the main text we showed that a combination of exogenous shocks that raises relative Home real investment spending, without affecting the terms of trade has these consequences: relative Home wage income rises, and the relative dividend of the Home firm falls. The same logic also applies directly to capitalized income streams, and thus to returns. Consider a combination of exogenous innovations that raises the present discounted value of relative Home real investment spending, without changing the present value of (current and future) Home terms of trade; that combination of shocks raises the present value of relative Home wage income, while lowering the present value of relative Home dividends; in other terms, such a combination of shocks has no effect on the return differential between Home-good and Foreign-good bonds, and no effect on the present value of efficient relative Home consumption spending; however, it raises the relative return on Home human capital, while reducing the relative return of the Home stock. Holding constant the bond return differential, the relative return on Home human capital co-moves thus negatively with the relative Home stock return: $\operatorname{Cov}_{R^{b}}\left(R_{t}^{W}, R_{t}^{S}\right)<0$. 


\section{- References}

[1] Acemoglu D. and J. Ventura, 2002, The World Income Distribution, Quarterly Journal of Economics, 117, 659-94.

[2] Adler, M. and B. Dumas, 1983, International Portfolio Choice and Corporation Finance: a Synthesis, Journal of Finance, 38, 925-984.

[3] Backus, D., and G.W, Smith, 1993, Consumption and Real Exchange Rates in Dynamic Economies with Non-traded Goods, Journal of International Economics, 35, 297-316.

[4] Backus, D., P. Kehoe and F. Kydland, 1994. Dynamics of the Trade Balance and the Terms of Trade: The J-Curve? American Economic Review, 84, 84-103.

[5] Baxter, M. and U. Jermann, 1997, The International Portfolio Diversification is Worse Than You Think, American Economic Review, 87, 170-80.

[6] Bottazzi, L., P. Pesenti and E. Van Wincoop, 1996, Wages, Profits and the International Portfolio Puzzle, European Economic Review, 40, 219-254.

[7] Cantor R. and N. Mark. 1988, The International Transmission of Real Business Cycles, International Economic Review 29, 493-507.

[8] Castello M., 2007, A New Open Economy Macroeconomic Model with Endogenous Portfolio Diversification and Firm Entry, Working Paper, European University Institute.

[9] Coeurdacier, N., 2005, Do Trade Costs in Goods Markets Lead to Home Bias in Equities? Working Paper, ESSEC.

[10] Coeurdacier, N. and S. Guibaud, 2006, A Dynamic Equilibrium Model of Imperfectly Integrated Financial Markets, Paris School of Economics, Working Paper 2005-24.

[11] Coeurdacier, N., R. Kollmann and P. Martin, 2007, International Portfolios with Supply, Demand and Redistributive Shocks, National Bureau of Economic Research, Working Paper 13424.

[12] Coeurdacier, N. and Gourinchas P-O, 2008, Home Bias in Goods and Assets: the Role of Bond Trading, Working Paper, University of Berkeley.

[13] Cole, H., M. Obstfeld, 1991, Commodity Trade and International Risk Sharing: How Much do Financial Markets Matter? Journal of Monetary Economics, 28, 3-24. 
[14] Collard, F., H. Dellas, B. Diba and A. Stockman, 2007, Home Bias in Goods and Assets, Mimeo, Working Paper, IDEI-University of Toulouse.

[15] Corsetti, G., L. Dedola and S. Leduc, 2007, International Risk-Sharing and the Transmission of Productivity Shocks, Working Paper, European Central Bank, forthcoming Review of Economic Studies.

[16] Devereux, M. and M. Saito, 2005, A Portfolio Theory of International Capital Flows, Working Paper, University of British Columbia.

[17] Devereux, M. and A. Sutherland, 2006a, Solving for Country Portfolios in Open Economy Macro Models, Working Paper, University of British Columbia and St. Andrews University.

[18] Devereux, M. and A. Sutherland, 2006b, Country Portfolio Dynamics, Working Paper, University of British Columbia and St. Andrews University.

[19] Engel, C. and A. Matsumoto, 2006, Portfolio Choice in a Monetary Open-Economy DSGE Model, National Bureau of Economic Research, Working Paper 12214.

[20] Evans, M. and V. Hnatkovska, 2005, International Capital Flows Returns and World Financial Integration, National Bureau of Economic Research, Working Paper 11701.

[21] Evans, M. and V. Hnatkovska, 2007, Solving General Equilibrium Models with Incomplete Markets and Many Financial Assets, Working Paper, Georgetown University.

[22] Faruqee, H. and J. Lee, 2007, Global Dispersion of Current Accounts: Is the Universe Expanding? Working Paper, IMF.

[23] Fisher, J., 2002. Technology Shocks Matter. Working Paper, Federal Reserve Bank of Chicago.

[24] Fisher, J., 2006.The Dynamic Effects of Neutral and Investment-Specific Technology Shocks, Journal of Political Economy, 114, 413-52.

[25] French, K. and J. Poterba, 1991, Investor Diversification and International Equity Markets, American Economic Review, 81, 222-26.

[26] Ghironi, F., J. Lee and A. Rebucci, 2006, The Valuation Channel of External Adjustment, Working Paper, Boston College. 
[27] Gourinchas, P-O and H. Rey, 2005, International Financial Adjustment, National Bureau of Economic Research, Working Paper 11155.

[28] Greenwood, J., Z. Hercowitz and P. Krusell, 1997. Long-Run Implications of InvestmentSpecific Technological Change, American Economic Review, American Economic Association, vol. $87(3)$, pages $342-62$

[29] Greenwood, J., Z. Hercowitz and P. Krusell, 2000. The role of investment-specific technological change in the business cycle, European Economic Review 44, 91-115

[30] Hau, H. and H. Rey, 2004. Can Portfolio Rebalancing Explain the Dynamics of Equity Returns, Equity Flows and Exchange Rates? American Economic Review P\&P, 94, 126-133.

[31] Heathcote, J. and F. Perri, 2002, Financial Autarky and International Business Cycles, Journal of Monetary Economics, 49, 601-627.

[32] Heathcote, J. and F. Perri, 2004, Financial Globalization and Real Regionalization, Journal of Economic Theory, 119, 207-243.

[33] Heathcote, J. and F. Perri, 2007, The international diversification is not as bad as you think, National Bureau of Economic Research, Working Paper 13483.

[34] Helpman, E. and A. Razin, 1978, A Theory of International Trade Under Uncertainty, New York: Academic Press.

[35] Hnatkovska, V., 2005, Home Bias and High Turnover: Dynamic Portfolio Choice with Incomplete Markets, working paper, Georgetown University.

[36] Imbs, J. and I. Méjean, 2008, Elasticity Optimism, Working Paper, University of Lausanne.

[37] Julliard, C., 2004, Human Capital and International Portfolio Choice, Working Paper, Princeton University.

[38] Julliard, C., 2002, International Portfolio Diversification Is Not Worse Than You Think, Working Paper, Princeton University.

[39] Justiniano, A. and G. Primiceri, 2006. The Time Varying Volatility of Macroeconomic Fluctuations, American Economic Review, forthcoming, National Bureau of Economic Research, Working Paper No. 12022 
[40] Justiniano, A., G. Primiceri and A. Tambalotti, 2007. Investment Shocks and Business Cycles, Working Paper, Northwestern University.

[41] Kollmann, R., 1991, Essays on International Business Cycles, PhD Dissertation, Economics Department, University of Chicago.

[42] Kollmann, R., 1995, Consumption, Real Exchange Rates and the Structure of International Asset Markets, Journal of International Money and Finance, 1995, 14, 191-211.

[43] Kollmann, R., 1996, Incomplete Asset Markets and the Cross-Country Consumption Correlation Puzzle, Journal of Economic Dynamics and Control, 20, 945-962.

[44] Kollmann, R., 1998, US Trade Balance Dynamics: The Role of Fiscal Policy and Productivity Shocks and of Financial Market Linkages Journal of International Money and Finance, 17, 637-69.

[45] Kollmann, R., 2006a, A Dynamic General Equilibrium Model of International Portfolio Holdings: Comment, Econometrica, 74, 269-273.

[46] Kollmann, R., 2006b, International Portfolio Equilibrium and the Current Account, Centre for Economic Policy Research, Working Paper 5512.

[47] Kollmann, R., 2006c, Comment on 'International Prices and Productivity: an Empirical Analysis of the Transmission among OECD Countries', NBER International Seminar on Macroeconomics, Vol. 3, 2006 (forthcoming).

[48] Kraay, A., N. Loayza, L. Serven and J. Ventura, 2005. Country Portfolios. Journal of the European Economic Association, 3 (4), 914-945.

[49] Lane, P. and G.M. Milesi-Feretti, 2003, International Financial Integration, IMF Staff Papers, 50., 82-113.

[50] Lane, P. and G.M. Milesi-Ferretti, 2005, A Global Perspective on External Positions, IIIS Discussion Paper 79, Trinity College Dublin.

[51] Lane, P. and G.M. Milesi-Ferretti, 2006, The External Wealth of Nations Mark II, IMF Working Paper 06-69.

[52] Lewis, K., 1999, Explaining Home Bias in Equities and Consumption, Journal of Economic Literature, 37, 571-608. 
[53] Martin, P. and H. Rey, 2004, Financial Super-Markets: Size Matters for Asset Trade, Journal of International Economics, 64, 335-361.

[54] Matsumoto, A., 2007, The Role of Nonseparable Utility and Nontradeables in International Business Cycle and Portfolio Choice, IMF working paper 7163.

[55] McElroy, T., 2008, Exact formulas for the Hodrick-Prescott filter, Econometrics Journal, 11, 209-217.

[56] Obstfeld, M. and K. Rogoff, 1996, Foundations of International Macroeconomics, Cambridge, MA: MIT Press.

[57] Obstfeld, M., 2006, International Risk Sharing and the Costs of Trade, Ohlin Lecture, Stockholm School of Economics.

[58] Pavlova, A. and R. Rigobon, 2004, Asset Prices and Exchange Rates, Review of Financial Studies, forthcoming.

[59] Pavlova, A. and R. Rigobon, 2007, An Asset-Pricing View of External Adjustment, LBS Working Paper.

[60] Raffo, A., 2008, Technology Shocks: Novel Implications for International Business Cycles, Working Paper, FRB.

[61] Sachs, J., 1981, The Current Account and Macroeconomic Adjustment in the 1970s, Brookings Papers on Economic Activity, Vol. 1981, No.1, 201-268.

[62] Sercu, P. and R. Vanpée, 2007, Home Bias in International Equity Portfolios: A Review, Working Paper, Leuven School of Business and Economics.

[63] Sims, C., 2000, Second Order Accurate Solution of Discrete Time Dynamic Equilibrium Models, Working Paper, Princeton University.

[64] Siourounis, G., 2004, Capital Flows and Exchange Rates: an Empirical Analysis, Working Paper, London Business School.

[65] Tesar, L. and I. Werner, 1995, Home Bias and High Turnover, Journal of International Money and Finance 14, 467-92. 
[66] Tille, C., 2005, Financial Integration and the Wealth Effect of Exchange Rate Fluctuations, Federal Reserve Bank of New York Staff Report 226.

[67] Tille, C. and E. Van Wincoop, 2007, International Capital Flows, National Bureau of Economic Research, Working Paper 12856.

[68] Uppal, R., 1993, A General Equilibrium Model of International Portfolio Choice, Journal of Finance, 48, 529-553.

[69] Warnock, F., 2002, Home Bias and High Turnover Reconsidered, Journal of International Money and Finance 21, 795-805.

[70] Van Nieuwerburgh, S. and L. Veldkamp, 2007, Information Immobility and the Home Bias Puzzle, Working Paper, New York University.

[71] Van Wincoop, E. and F. Warnock, 2006, Is Home Bias in Assets Related to Home Bias in Goods? National Bureau of Economic Research, Working Paper 12728. 
Table 1. Correlations between relative labor incomes and dividends, and implied locally held equity shares

\begin{tabular}{|c|c|c|c|c|c|c|c|}
\hline & US & Japan & Germany & France & UK & Italy & Canada \\
\hline $\operatorname{Corr}\left(\widehat{w_{t} l_{t}}, \widehat{d_{t}}\right)$ & $\begin{array}{l}0.73 \\
(.12)\end{array}$ & $\begin{array}{l}0.59 \\
(.08)\end{array}$ & $\begin{array}{l}0.70 \\
(.14)\end{array}$ & $\begin{array}{l}0.77 \\
(.12)\end{array}$ & $\begin{array}{r}-0.24 \\
(.12)\end{array}$ & $\begin{array}{l}0.89 \\
(.02)\end{array}$ & $\begin{array}{l}0.28 \\
(.11)\end{array}$ \\
\hline $\operatorname{Corr}_{\widehat{q}_{t}}\left(\widehat{w_{t} I_{t}}, \widehat{d_{t}}\right)$ & $\begin{array}{r}-0.17 \\
(.15)\end{array}$ & $\begin{array}{r}-0.75 \\
(.05)\end{array}$ & $\begin{array}{r}-0.69 \\
(.10)\end{array}$ & $\begin{array}{r}-0.39 \\
(.07)\end{array}$ & $\begin{array}{r}-0.71 \\
(.11)\end{array}$ & $\begin{array}{r}-0.26 \\
(.19)\end{array}$ & $\begin{array}{r}-0.22 \\
(.16)\end{array}$ \\
\hline $\begin{array}{l}\text { Implied locally } h \\
\text { equity share } S_{i}^{i}\end{array}$ & $\begin{array}{l}0.58 \\
(.17)\end{array}$ & $\begin{array}{l}1.03 \\
(.16)\end{array}$ & $\begin{array}{l}0.50 \\
(.09)\end{array}$ & $\begin{array}{l}0.51 \\
(.23)\end{array}$ & $\begin{array}{l}0.68 \\
(.13)\end{array}$ & $\begin{array}{l}0.34 \\
(.24)\end{array}$ & $\begin{array}{l}0.18 \\
(.14)\end{array}$ \\
\hline
\end{tabular}

\section{Notes}

$\operatorname{Corr}\left(\widehat{w_{t} l_{t}}, \widehat{d}_{t}\right)$ : correlation between relative labor income and the relative dividend income in a given country (compared to total labor income and total dividend in remaining G7 countries).

$\operatorname{Corr}_{\widehat{\boldsymbol{q}}_{t}}\left(\widehat{w}_{\boldsymbol{t}} \widehat{\boldsymbol{l}}_{t}, \widehat{\boldsymbol{d}}_{t}\right)$ : correlation between components of relative labor income and the relative dividend income that are orthogonal to terms of trade.

Implied locally held equity share $S_{i}^{i}$ : value of $S_{i}^{i}$ implied by $\operatorname{Corr}_{\widehat{q}_{t}}\left(\widehat{w_{t} l_{t}}, \widehat{d}_{t}\right)$.

The data are annual, 1984-2004. Figures in parentheses are standard errors (based on GMM). See text for further explanations. 


\begin{tabular}{lrrrrrrrr}
\hline \hline Standard deviations (\%) & US & JA & GE & FR & UK & IT & CA & Mean \\
GDP & 1.58 & 2.94 & 1.67 & 1.61 & 2.12 & 1.76 & 2.80 & 2.07 \\
Investment & 7.17 & 7.66 & 6.08 & 7.40 & 7.20 & 5.07 & 7.65 & 6.89 \\
Net exports & 0.72 & 0.63 & 0.85 & 0.87 & 1.81 & 1.61 & 1.50 & 1.14 \\
(Net foreign assets) & 2.36 & 2.60 & 2.63 & 4.33 & 5.02 & 2.67 & 3.03 & 3.23 \\
(Net foreign bond assets) & 0.85 & 1.60 & 2.88 & 2.37 & 3.18 & 2.59 & 1.91 & 2.20 \\
(N (Net foreign equity assets) & 2.27 & 3.20 & 1.37 & 4.69 & 4.20 & 2.35 & 2.74 & 2.97 \\
Current account & 0.77 & 0.62 & 1.73 & 0.75 & 1.35 & 1.34 & 1.17 & 1.11 \\
Net bond purchases & 0.88 & 1.25 & 2.49 & 1.76 & 2.24 & 1.92 & 1.45 & 1.71 \\
Net equity purchases & 0.90 & 1.02 & 1.59 & 1.67 & 1.75 & 1.70 & 1.06 & 1.38 \\
Real exchange rate & 10.03 & 10.51 & 8.05 & 7.45 & 6.47 & 9.65 & 6.49 & 8.38
\end{tabular}

Correlations with domestic GDP

Net exports

$\Delta$ (Net foreign bond assets)

$\Delta$ (Net foreign equity assets)

Current account

Net bond purchases

Net equity purchases

Real exchange rate
$\Delta$ (Net foreign assets) $\frac{-0.38}{-0.27}$

$\underline{-0.27}$

$\underline{-0.43}$

$\underline{\mathbf{0 . 5 2}} \quad \frac{-0.48}{-0.06}$

$\underline{\underline{\mathbf{0 . 7 7}}}-0.08$

0.07 $\underline{-0.56}$

$-0.00$

$\underline{-0.23}$

$\underline{0.20}$

$-0.48$

0.17

\begin{tabular}{ll}
$\frac{\mathbf{- 0 . 2 9}}{\mathbf{- 0 . 2 4}}$ & $\frac{\mathbf{- 0 . 5 2}}{-0.18}$ \\
$\frac{\mathbf{- 0 . 3 8}}{\mathbf{0 . 3 1}}$ & $\frac{\mathbf{- 0 . 5 0}}{0.11}$ \\
$\frac{\mathbf{- 0 . 5 4}}{\mathbf{- 0 . 3 5}}$ & -0.32 \\
\hline 0.07 & $\frac{\mathbf{- 0 . 5 9}}{\mathbf{0 . 5 5}}$ \\
-0.04 & -0.18
\end{tabular}

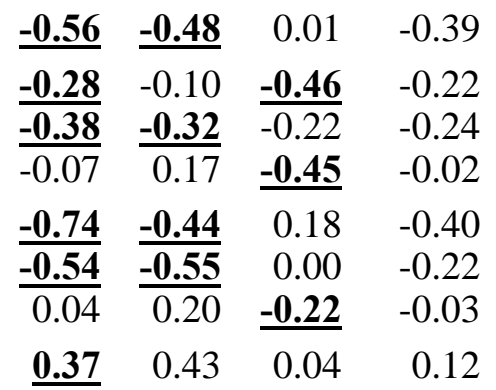

Autocorrelations

GDP

$\Delta$ (Net foreign assets)

$\Delta$ (Net foreign bond assets)

$\Delta$ (Net foreign equity assets)

Current account

Net bond purchases

Net equity purchases

$\begin{array}{lrlrrrrr}\underline{\mathbf{0 . 6 8}} & \underline{\mathbf{0 . 8 4}} & \underline{\mathbf{0 . 6 8}} & \underline{\mathbf{0 . 7 2}} & \underline{\mathbf{0 . 7 6}} & \underline{\mathbf{0 . 7 1}} & \underline{\mathbf{0 . 7 8}} & 0.74 \\ 0.03 & \underline{\mathbf{- 0 . 4 2}} & 0.00 & -0.13 & -0.14 & -0.01 & \underline{\mathbf{0 . 5 8}} & -0.01 \\ \underline{\mathbf{0 . 2 7}} & 0.13 & 0.12 & 0.09 & \underline{\mathbf{0 . 1 4}} & 0.10 & 0.12 & 0.14 \\ \underline{\mathbf{0 . 2 6}} & \underline{\mathbf{- 0 . 2 3}} & 0.12 & -0.17 & -0.16 & 0.17 & 0.16 & 0.02 \\ \underline{\mathbf{0 . 7 1}} & \underline{\mathbf{0 . 4 6}} & \underline{\mathbf{0 . 6 6}} & \underline{\mathbf{0 . 6 7}} & \underline{\mathbf{0 . 7 0}} & \underline{\mathbf{0 . 7 3}} & \underline{\mathbf{0 . 5 5}} & 0.64 \\ \underline{\mathbf{0 . 6 5}} & \underline{\mathbf{0 . 2 6}} & \underline{\mathbf{0 . 6 6}} & 0.11 & 0.17 & \underline{\mathbf{0 . 3 9}} & -0.01 & 0.32 \\ \underline{\mathbf{0 . 5 8}} & -0.00 & \underline{\mathbf{0 . 4 1}} & \underline{\mathbf{0 . 3 5}} & -0.17 & \underline{\mathbf{0 . 5 0}} & -0.08 & 0.23\end{array}$

\section{Other correlations}

$\Delta$ (Net foreign equity assets) \&

$\begin{array}{llllllllll}\Delta \text { (Net foreign bond assets) } & -0.09 & \underline{\mathbf{0 . 4 8}} & \underline{\mathbf{0 . 3 9}} & \underline{\mathbf{- 0 . 3 9}} & -0.01 & \underline{\mathbf{- 0 . 3 6}} & -0.15 & -0.27\end{array}$

Net equity purchases \&

Net bond purchases

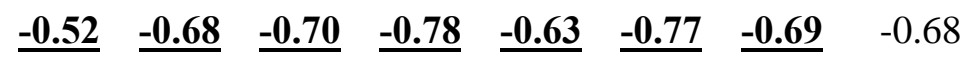

Notes--Data are annual, 1984-2004, and were Hodrick-Prescott filtered. GDP, investment and real exchange rate series were logged. Real exchange rates are CPI-based. Underlined correlations are statistically significant at a $10 \%$ level (two-sided test, GMM based, assuming 4-th order serial correlation in residuals). JA: Japan, GE: Germany, FR: France, IT: Italy, CA: Canada. 


\section{$\theta_{H}, \theta_{F}$}

$\chi_{H}, \chi_{F} \quad \theta_{H}, \theta_{F} \quad \chi_{H}, \chi_{F}$

(1)

Standard deviations (\%)

GDP

Investment

Net exports

$\Delta$ (Net foreign assets)

$\Delta$ (Net foreign bond assets)

$\Delta$ (Net foreign equity assets)

Current account

Net bond purchases

Net equity purchases

Real exchange rate

(2)

1.87

8.26

1.07

1.65

4.73

0.24

1.39

3.69

2.31

5.32

3.13

0.00

0.00

$3.23 \quad 2.39$

$3.23 \quad 2.39$

1.38

0.60

(3)

0.88

6.77

1.05

1.72

3.82

2.11

0.00

2.18

2.18

1.24 $\begin{array}{lll}-0.07 & 0.06 & -0.17\end{array}$

$-0.39$

$-0.26$

$-0.32$

$-0.20$

$-0.17$

0.15

$0.23 \quad 0.28$

$\begin{array}{rrr}-- & -- & -- \\ -0.27 & -0.30 & -0.22\end{array}$

$\begin{array}{lll}0.27 & 0.30 & 0.22\end{array}$

$\begin{array}{lll}-0.22 & -0.52 & -0.07\end{array}$

$-0.22$

$-0.24$

$-0.02$

$-0.40$

$-0.22$

$-0.03$

0.12

Real exchange rate

Autocorrelations

GDP

$\begin{array}{rrrr}0.59 & 0.55 & 0.76 & 0.74 \\ 0.12 & -0.03 & 0.21 & -0.01 \\ 0.04 & -0.07 & 0.15 & 0.14 \\ -0.00 & -0.10 & 0.10 & 0.02 \\ -- & -- & -- & 0.64 \\ 0.07 & -0.06 & 0.23 & 0.32 \\ 0.07 & -0.06 & 0.23 & 0.23\end{array}$

Other correlations

$\Delta$ (Net foreign equity assets) \&

$\Delta$ (Net foreign bond assets)

$-0.99 \quad-0.99 \quad-0.99$

$-0.27$

Net bond purchases \&

Net equity purchases

$-1.00 \quad-1.00 \quad-1.00$

$-0.68$

Notes--The following variables are normalized by domestic GDP: Net exports, $\Delta$ (Net foreign assets), $\Delta$ (Net foreign bond assets), $\Delta$ (Net foreign equity assets), Current account, Net bond purchases, Net equity purchases. GDP, Investment and the Real exchange rate (CPI-based) are logged. All variables are Hodrick-Prescott filtered. 